\title{
Habitat, distribution and status of the Azure-rumped Tanager Tangara cabanisi in Mexico
}

\author{
MELANIE HEATH and ADRIAN LONG
}

\begin{abstract}
Summary
The Azure-rumped Tanager Tangara cabanisi is a threatened species confined to the mountains of the Sierra Madre de Chiapas in Mexico and neighbouring Guatemala. It occurs on the Pacific and Gulf slopes of the mountain range, but most frequently on the former between 1,000 and 1,700 m. The Azure-rumped Tanager's habitat is a medium height (about $30 \mathrm{~m}$ tall) humid evergreen broadleaf forest formation containing elements of both mesophilous forest of higher altitudes and tropical forests of the lowlands. Information from field surveys and more general data from vegetation maps was combined using a geographical information system package to extrapolate and predict distribution of potential Azure-rumped Tanager habitat in the Sierra Madre de Chiapas. It is estimated that a maximum of 112,000 ha remain, although the total was probably never greater than 200,000 ha. Fortunately 43,660 ha $(39 \%)$ of the maximum total is contained within the El Triunfo Biosphere Reserve, a newly decreed protected area that spans both the Pacific and Gulf slopes in the central portion of the mountain range. Most of the suitable habitat is found within the reserve's buffer zone, an area in which there are several small but expanding communities. The effective protection and future status of the species rests heavily on the conservation of this habitat within the reserve and essentially this depends on the collaboration in favour of conservation between the local people and the conservation managers and, ultimately, the development of viable landuse alternatives that are less damaging to the forest ecosystem.
\end{abstract}

Tangara cabanisi es una especie amenazada cuya distribución queda restringida a las montañas de la Sierra Madre de Chiapas en México y en la zona adyacente de Guatemala. Habita las laderas de la sierra de la vertiente Pacífica y Atlántica, siendo más frecuente en la primera en altitudes comprendidas entre los 1,000 y los 1,700 $\mathrm{m}$. El hábitat de Tangara cabanisi consiste en un bosque tropical húmedo perennifolio de altura intermedia (unos $30 \mathrm{~m}$ ), integrado por elementos florísticos mesófilos propios de cotas superiores y de las selvas de las zonas bajas. La información recogida durante el trabajo de campo, junto con datos más generales procedentes de mapas de vegetación de la zona, se combinaron mediante Sistemas de Información Geográfica (SIG) que permitió extrapolar y predecir la distribución del tipo de hábitat susceptible de ser utilizado por la especie en la Sierra Madre de Chiapas. Se ha estimado la existencia de un máximo de 112,00o ha que satisfacen los requerimientos ecológicos de la especie y quizás nunca fue superior a las 200,000 ha. Afortunadamente 43,660 ha del mencionado hábitat quedan incluidas dentro de la Reserva de la Biosfera "El Triunfo" de reciente creación, que se extiende en sendas vertientes en la zona central del sistema montañoso de la Sierra Madre de Chiapas. A su vez, la mayor parte del hábitat potencial para la especie se halla en la zona de amortiguamiento, en la que subsisten varias comunidades pequeñas, hoy en expansión. La protec- 
ción efectiva y el estado de la especie en el futuro radica sin lugar a dudas en la conservación de este ecosistema peculiar dentro de la reserva, que al mismo tiempo depende de la colaboración de los habitantes locales en favor de la conservación y su respaldo al personal responsable de la gestión del área y en última instancia de la puesta en práctica de una utilización de la tierra racional que sea lo menos perjudicial para el ecosistema.

\section{Introduction}

The Azure-rumped Tanager Tangara cabanisi is endemic to the mountains of the Sierra Madre de Chiapas, Mexico, and neighbouring Guatemala, and is one of the least known species in the genus, given "Indeterminate" status in the second edition of the bird Red Data Book (King 1978-1979). All past records of the Azure-rumped Tanager for Chiapas and Guatemala are listed in Table 1, their location shown on Figure 1: they consist of five specimens from four localities, and sightings from three additional areas. All of these records are from the Pacific slope of the mountain chain covering an altitudinal range of between 600 and $1,600 \mathrm{~m}$.

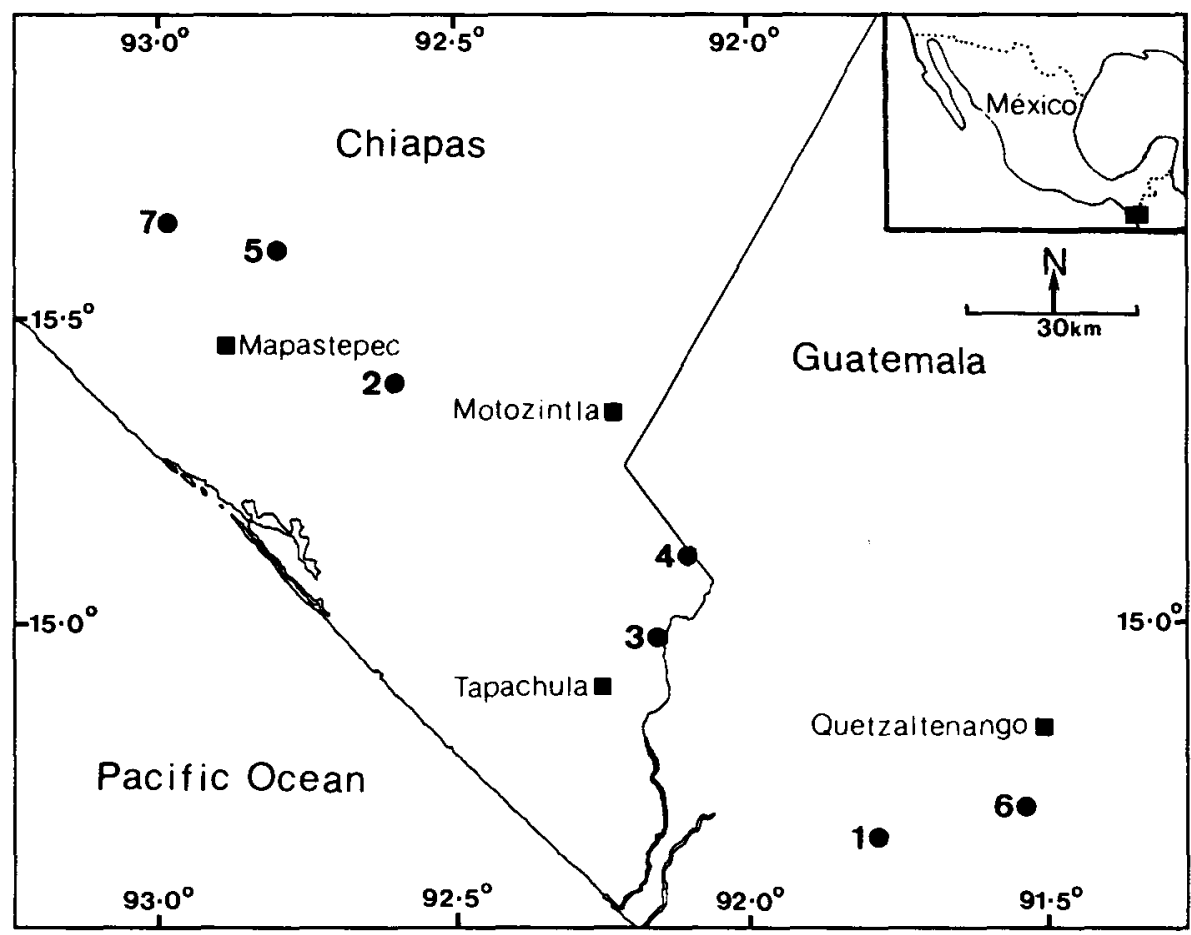

Figure 1. The location of past records of the Azure-rumped Tanager in Chiapas and Guatemala. 1, Costa Cuca (district of); 2, Monte Ovando; 3, Cacahoatán; 4, Volcán Tacaná; 5, El Triunfo trail (around Cañada Honda); 6, Volcán Santa María (vicinity of); 7, San Antonio Miramar. 


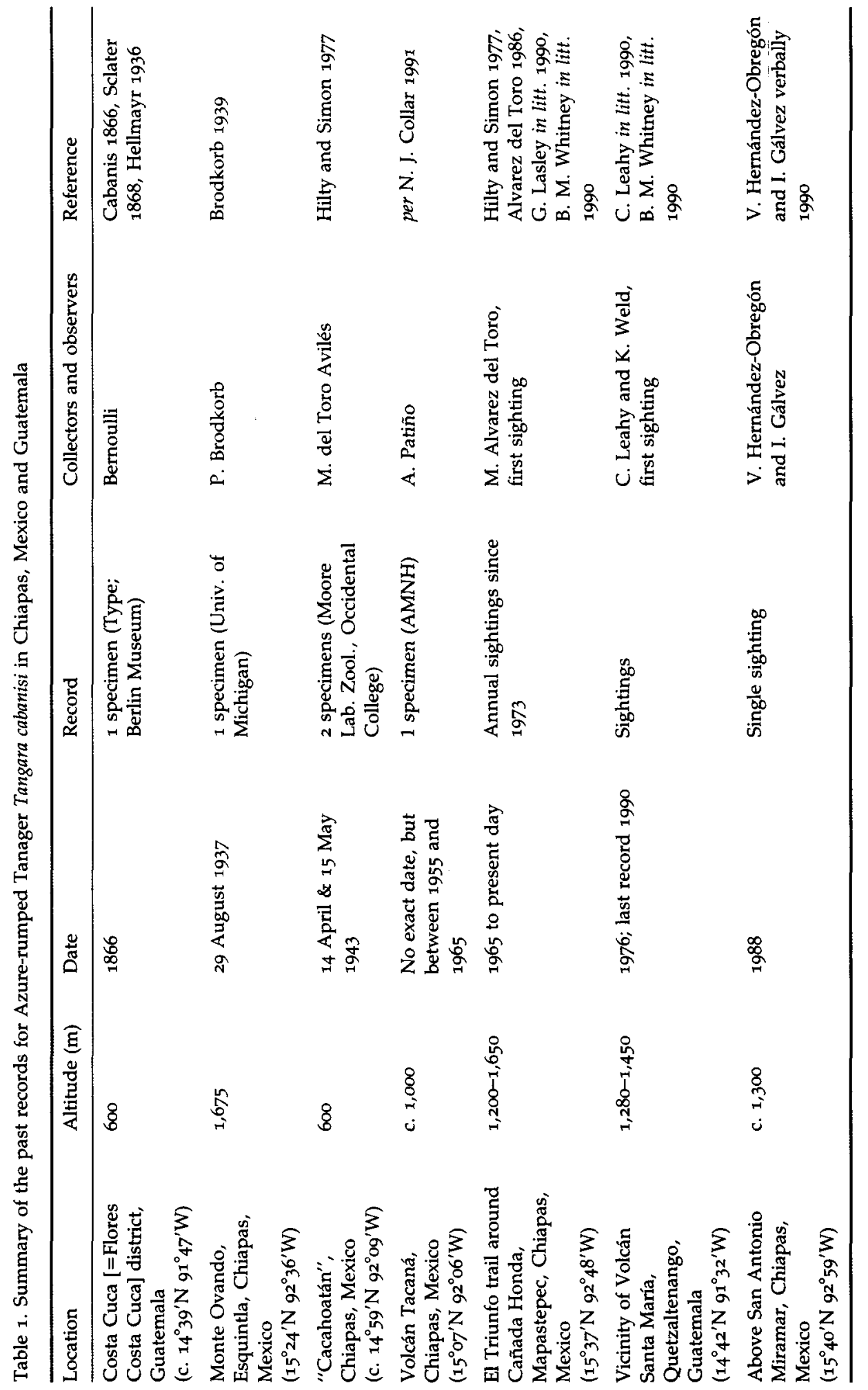


There are doubts, however, concerning the precise localities of the specimens collected below 1,000 $\mathrm{m}$, namely the type-specimen from the district of Costa Cuca, Guatemala, and two specimens from Cacahoatán, Chiapas. Land (1970) indicates that some ambiguity exists concerning the location of the type-specimen since he could not find Costa Cuca or the district boundaries on maps that he checked. However, the village reappears as Flores Costa Cuca on maps published in 1971 by the Instituto Geográfica de Guatemala (C. Leahy in litt. 1989) and apparently lies at an elevation of $550 \mathrm{~m}$ in the foothills above the Pacific coastal plain. Volcán Santa María is found only $30 \mathrm{~km}$ west-south-west, where the species has been seen occasionally since its discovery there by $C$. Leahy and K. Weld in 1976.

The data accompanying the Chiapas specimens collected by $\mathrm{M}$. del Toro Avilés are imprecise, and indeed confusion has arisen regarding other specimens collected by him in Chiapas and Oaxaca. Binford (1989) and Crossin and Ely (1973) have questioned the validity of data given on his specimen labels, and state that some localities are incorrect and elevations variable and are therefore untrustworthy. Apparently, the labels for the two Azure-rumped Tanager specimens bear the collecting locality of "Cacahoatán" (Moore Laboratory of Zoology, Occidental College), but this is unclear since the town of Cacahoatán (at c. $600 \mathrm{~m}$ ) gives its name to the municipality in which it lies. This small municipality contains much land above $1,000 \mathrm{~m}$; indeed the southern slope of Volcán Tacaná, where an Azure-rumped Tanager was collected between 1955 and 1965 (see Table 1), lies in the northern part.

The Azure-rumped Tanager has been regularly sighted at only one locality, namely a section of the "El Triunfo trail", the path which traverses the central portion of the Sierra Madre de Chiapas. This path extends from Ejido Tres de Mayo $\left(15^{\circ} 34^{\prime} \mathrm{N} 92^{\circ} 5^{\prime} \mathrm{W}\right)$ at $550 \mathrm{~m}$ in the lowlands above the Pacific coastal plain, climbs to a plateau at $1,900 \mathrm{~m}$ where the $\mathrm{El}$ Triunfo camp is located, and then descends to Finca Prusia $\left(15^{\circ} 42^{\prime} \mathrm{N} 92^{\circ} 4^{\prime} \mathrm{W}\right)$ at $1,000 \mathrm{~m}$ on the Gulf slope. The discovery of the species along the Pacific slope of this trail in 1965 (Alvarez del Toro 1986) stimulated great interest, and since 1973 (owing mainly to the visits of Victor Emanuel Nature Tours) the species has been observed here annually (Hilty and Simon 1977, G. Lasley in litt. 1989). The observations have largely centred around Cañada Honda $\left(15^{\circ} 37^{\prime} \mathrm{N} 92^{\circ} 48^{\prime} \mathrm{W}\right)$ at an elevation of $1,450 \mathrm{~m}$ (Hilty and Simon 1977, Jost 1989, G. Lasley in litt. 1989, B. M. Whitney in litt. 1990, I. Gálvez verbally 1990). Cañada Honda is a deep valley through which the Río Honda flows (a tributary of the Río Novillero), but the name more specifically refers to a formerly cleared area of 1-2 ha within this valley and whose vegetation has now regenerated to a height of $5 \mathrm{~m}$. The tanager is seen more easily in this small area since the vegetation is low and the slopes steep, affording good views of the birds as they fly from one side of the canyon to the other.

These past observations along the El Triunfo trail have provided the little published information that is available on the ecology of the Azure-rumped Tanager. Hilty and Simon (1977) outline the bird's general behaviour, song, feeding, species affinities, numbers, altitude range and general habitat, based on sightings in 1973 and 1974. They describe it as a forest-dwelling species, spending the majority of its time in the upper strata and canopy of the tallest trees. More recently in this area, in the 1980s, two tanager nests were found (Isler and 
Isler 1987, G. Lasley in litt. 1989, B. M. Whitney in litt. 1990), one of which was filmed and photographed (A. Huc verbally 1990).

Several of the past records give some description of Azure-rumped Tanager habitat. These include: Brodkorb (1939), who shot the tanager from the top of a tall tree on the edge of a small clearing in cloud-forest at Monte Ovando; Hilty and Simon (1977), who state that the forest where the species was observed along the El Triunfo trail is humid evergreen broadleaf forest; C. Leahy in litt. (1990), who describes the forest on the slopes of Volcán Santa Mariá, Guatemala, as wet subtropical evergreen forest. However, there remains overall a lack of detailed information on the plant species composition of the Azure-rumped Tanager habitat, while the differences between tanager and non-tanager habitat have not been clarified. Additionally very little is known about the extent or distribution of the Azure-rumped Tanager in the Sierra Madre de Chiapas and Guatemala.

This paper presents a study of the habitat and distribution of the Azurerumped Tanager in Chiapas, Mexico. A detailed investigation of the species's habitat and altitudinal limits was carried out in an area along the El Triunfo trail. Information from field surveys and more general data taken from vegetation maps were then combined using geographical information systems (GIS) to extrapolate and predict the overall distribution of the Azure-rumped Tanager in the Sierra Madre de Chiapas.

\section{Azure-rumped Tanager habitat}

\section{Study area}

The forest in the vicinity of the El Triunfo trail, the location of regular Azurerumped Tanager records, was selected for a detailed study of the species's habitat. Figure 2 shows the location of the El Triunfo trail; it is in Polygon 1 of the El Triunfo Biosphere Reserve, a recently decreed protected area covering 119,000 ha. The climate is humid-temperate in nature and, depending on elevation, the area receives between 2,500 and $4,000 \mathrm{~mm}$ rainfall a year, the majority occurring between May and November, with a mean annual temperature of 18$22^{\circ} \mathrm{C}$ (García 1981, IHN 1988).

Fieldwork was carried out between April 1989 and June 1990, and during the early part of the study period we surveyed the El Triunfo trail many times to gain familiarity with the area and assess the distribution and altitudinal limits of the species. It was found to occur between 1,050 and $1,700 \mathrm{~m}$ on the Pacific slope, but was most frequently sighted between $1,250 \mathrm{~m}$ and $1,650 \mathrm{~m}$, in accordance with past observations of the birds in the area (see Introduction). Additional evidence supporting the lower limit comes from two groups of visiting ecologists (including experienced ornithologists) who spent over three weeks in July to August of 1988 and 1989 on the Pacific slope between 450 and $1,100 \mathrm{~m}$ and only $10 \mathrm{~km}$ from the El Triunfo trail. They failed to locate the Azurerumped Tanager although extensive tracts of pristine forest were found (UEA 1989, 1990, I. Gálvez verbally 1990, pers. obs.).

Within the 1,250 to $1,650 \mathrm{~m}$ altitudinal range of the Pacific slope along the El Triunfo trail, the Azure-rumped Tanager did not appear to show any preference 


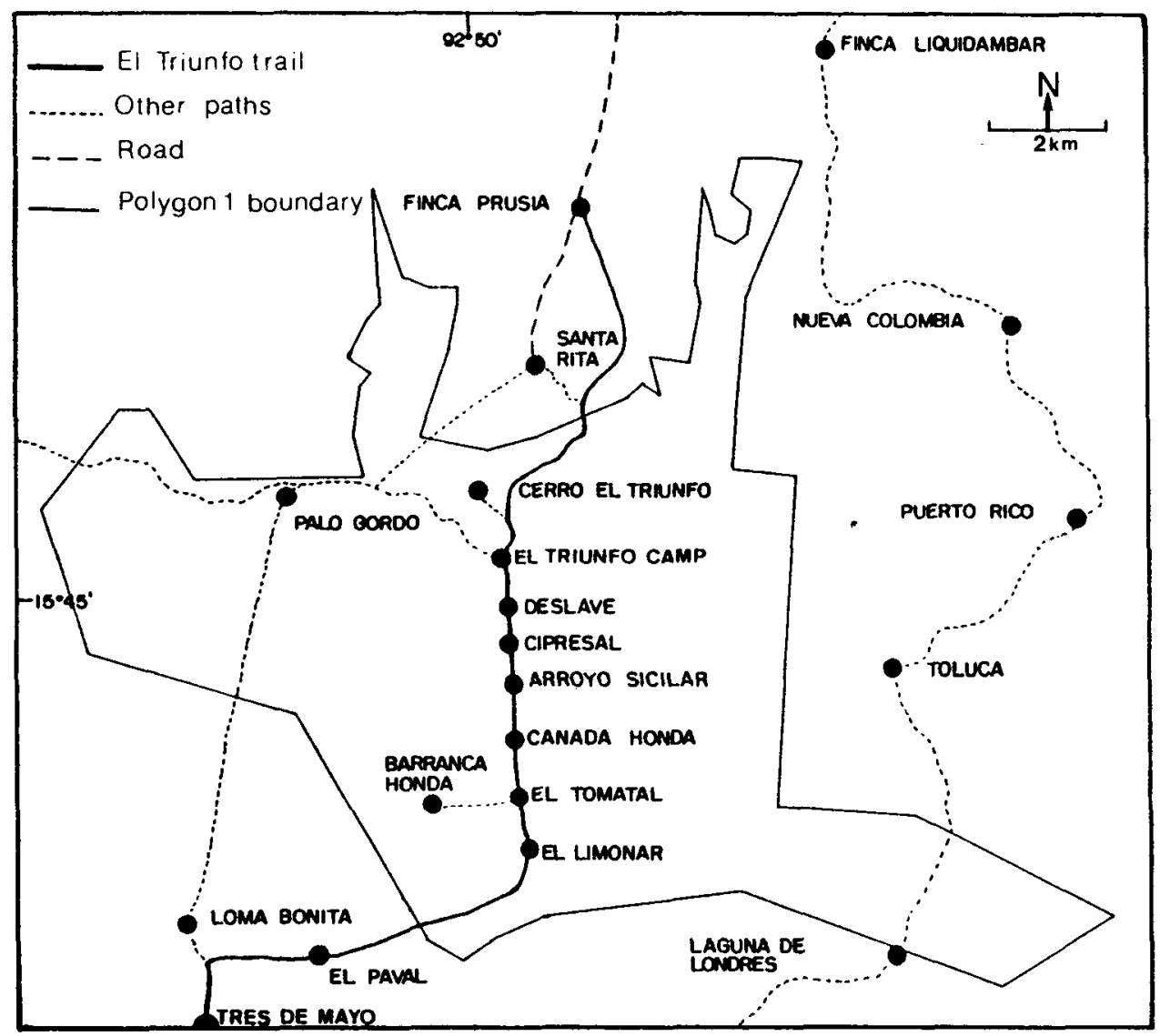

Figure 2. The location of the El Triunfo trail in relation to Polygon I of the El Triunfo Biosphere Reserve.

for particular areas, and it was observed daily with several nests of the species also being found. The tanager was usually seen in groups of up to six individuals, although other observers have noted larger groups: of 16 (Hilty and Simon 1977) and, astonishingly, 30 in 1986 (Jost 1989).

\section{Methods}

Sampling was undertaken to gather quantitative information on frequency, density and dominance of the floral components of the Azure-rumped Tanager's habitat. A $2 \mathrm{~km}$ section of the El Triunfo trail with an altitudinal range of 1,350 to $1,500 \mathrm{~m}$ on the Pacific slope was chosen as the sampling area as this was encompassed in the core area of tanager sightings. Qualitative information was also collected from various widespread sites along the El Triunfo trail to describe the physiognomic characteristics of the forest and to compare and contrast tanager and non-tanager habitat.

Quantitative sampling This was carried out in February 1990, utilizing the 
experience gained from our work during the previous nine months on the flora of the region. Land on the Pacific slope is steeply sloping, frequently in excess of $60^{\circ}$, susceptible to landslides, and in some parts littered with rocks and boulders. In view of this, the Point Centre Quarter Method (PCQ) (MüllerDombois and Ellenberg 1974) was used, being a plotless sampling technique which avoids the establishment of plot boundaries.

The Azure-rumped Tanager is largely a canopy-dwelling species, and therefore only trees were sampled. Data were collected for two size-classes of tree. The first, and most relevant to the tanager, was of larger trees with a greater than $12 \mathrm{~cm}$ diameter at breast height (DBH), corresponding to those greater than $8 \mathrm{~m}$ in height. The second category was of smaller trees with $\mathrm{DBH}$ between 3 and $12 \mathrm{~cm}$, and included trees of between 3 and $8 \mathrm{~m}$ in height. To minimize disturbance in the forest the transect line followed the El Triunfo trail. Nineteen positions were fixed along the transect line at $100 \mathrm{~m}$ intervals, at which two PCQ sampling points were established, one each side and $10 \mathrm{~m}$ from the line. Data on both size-classes of trees were collected separately from the same sampling point.

Qualitative information Qualitative information was collected from 25 sites along the El Triunfo trail. Tree species present were recorded and their heights estimated and placed into broad and approximate height classes. Data were also taken on the shrub and herb layers, vines, creepers, ferns (terrestrial and epiphytic), aroids and other epiphytic growth. Collections of flowering and fruiting vascular plants including pteridophytes were made during all months of the study period except July, August and January. Plant identification was undertaken at the herbarium of the Instituto de Historia Natural de Chiapas (CHIP) and at the National Herbarium (MEXU), which houses an excellent collection of Chiapas specimens.

\section{Results}

Quantitative results The absolute and relative values for density, dominance and frequency were calculated for the species sampled in the two DBH sizeclasses. The relative values were summed to produce the importance value (Curtis 1959), which is an indication of how important each species is in the forest and from this the importance percentage was derived. Relative density, relative frequency and relative dominance values may also be interpreted as importance values.

Trees of $\mathrm{DBH}>12 \mathrm{~cm}$ comprised 61 species, representing 33 families, and for the smaller category 54 species from 31 families were sampled. The 20 trees with the highest importance percentages from each DBH size-class are shown in Tables 2 and 3. For both size-classes the most important 20 species account for approximately $70 \%$ of the importance percentage. Other species that were sampled are indicated in Appendix 2. The total density of larger trees in the forest is 488 individuals per hectare, and that of smaller trees is 2,768 individuals per hectare. Rubiaceae is the best represented family with five species sampled from each size-class and from a total of 30 species of tree and shrub collected in the forest between 1,050 and 1,700 $\mathrm{m}$ (Appendix 2). 
Table 2. The 20 tree species with highest importance percentages of $\mathrm{DBH}>12 \mathrm{~cm}$ sampled along the El Triunfo trail around Cañada Honda between 1,300 and 1,500 m.

\begin{tabular}{|c|c|c|c|c|}
\hline Species & $\begin{array}{c}\text { Relative } \\
\text { density } \\
(\%)\end{array}$ & $\begin{array}{c}\text { Relative } \\
\text { frequency } \\
(\%)\end{array}$ & $\begin{array}{c}\text { Relative } \\
\text { dominance } \\
(\%)\end{array}$ & $\begin{array}{c}\text { Importance } \\
\text { percentage } \\
(\%)\end{array}$ \\
\hline Ficus cookii & 3.94 & 4.48 & 44.91 & $17 \cdot 78$ \\
\hline Coccoloba matudae & 6.58 & $5 \cdot 97$ & 9.08 & 7.21 \\
\hline Dipholis minutiflora & 4.61 & 3.73 & 4.56 & $4 \cdot 30$ \\
\hline Roupala montana & 3.95 & 4.48 & 1.80 & $3 \cdot 41$ \\
\hline Saurauia madrensis & 4.61 & 4.48 & 0.71 & 3.26 \\
\hline Croton reflexifolius & 3.95 & 4.48 & 0.71 & 3.04 \\
\hline Lauraceae sp. & 2.63 & 2.99 & 2.85 & 2.82 \\
\hline Casearia tacanensis & 3.95 & 3.73 & 0.54 & 2.74 \\
\hline Sapium schippii & 3.29 & 2.98 & 1.84 & 2.71 \\
\hline Billia columbiana & 2.63 & 2.24 & 3.22 & 2.70 \\
\hline Podocarpus matudae & 2.63 & 2.24 & 2.55 & 2.47 \\
\hline Bursera simaruba & 1.97 & 1.49 & 2.99 & 2.15 \\
\hline Urera alceifolia & 1.97 & 2.24 & 2.18 & 2.13 \\
\hline Cupania aff. macrophylla & 2.63 & 2.24 & 1.42 & 2.10 \\
\hline Calyptranthes pallens & 2.63 & 2.24 & 1.11 & 1.99 \\
\hline Meliosma matudae & 2.63 & 2.24 & 0.77 & 1.88 \\
\hline Glossostipula concinna & 1.97 & 2.24 & 0.49 & 1.57 \\
\hline Oreopanax xalapensis & 1.31 & 1.49 & 1.85 & 1.55 \\
\hline Saurauia kegeliana & $x .97$ & 2.24 & 0.35 & 1.52 \\
\hline Parathesis sp. & 1.97 & 2.24 & 0.29 & 1.50 \\
\hline Total 20 species & 61.82 & 60.46 & 84.22 & 68.83 \\
\hline Other 41 species & 38.18 & 39.54 & $15 \cdot 7^{8}$ & 31.17 \\
\hline Total & 100.0 & 100.0 & 100.0 & 100.0 \\
\hline
\end{tabular}

In the larger size-class Ficus cookii had the highest importance percentage, far exceeding any other species sampled, but Coccoloba matudae was more frequent and dense within the study area. The high importance percentage for $F$. cookii is accounted for by its large basal area, the DBH commonly being in excess of $3 \mathrm{~m}$, resulting in a very high relative dominance value. Other species such as Saurauia madrensis and Croton reflexifolius occupy comparatively little space in the forest. They have low dominance values but are present in high densities and frequencies and therefore have high importance values.

Understandably, the accuracy of the results improves with an increase in the number of sampling points. Cottam and Curtis (1956) recommend that at least 20 points per stand be sampled. However, many species in tropical forests are extremely rare and represented by very few individuals. For instance, Campbell et al. (1986) found that for a 3 ha sample plot 99 species $(37 \%$ of the total) of trees of DBH $10 \mathrm{~cm}$ or more were represented by just one individual, with similar results being found within lowland tropical forest in Panama (Hubbell and Foster 1986). The diversity of tree species in Azure-rumped Tanager habitat is much lower than in lowland tropical forest, but undoubtedly if sampling had continued beyond 38 points more species would have been added. However, it is felt that the main tree species components of the forest were covered, and that their relative values of density, dominance and frequency would not change markedly with additional sampling. 
Table 3 . The 20 tree species of $\mathrm{DBH}$ of $3-12 \mathrm{~cm}$ with the highest importance percentages sampled along the El Triunfo trail around Cañada Honda between 1,300 and $1,500 \mathrm{~m}$.

\begin{tabular}{|c|c|c|c|c|}
\hline Species & $\begin{array}{c}\text { Relative } \\
\text { density } \\
(\%)\end{array}$ & $\begin{array}{c}\text { Relative } \\
\text { frequency } \\
(\%)\end{array}$ & $\begin{array}{c}\text { Relative } \\
\text { dominance } \\
(\%)\end{array}$ & $\begin{array}{c}\text { Importance } \\
\text { percentage } \\
(\%)\end{array}$ \\
\hline Mollinedia pallida & 13.16 & 11.11 & 14.44 & 12.90 \\
\hline Palicorea padifolia & 7.24 & 7.94 & 5.82 & 6.70 \\
\hline Croton reflexifolius & 5.26 & 5.56 & 6.98 & 5.93 \\
\hline Eugenia negrita & 3.95 & 3.97 & 6.42 & 4.77 \\
\hline Piper sp. & 5.26 & 3.97 & 3.86 & $4 \cdot 36$ \\
\hline Koanophyllon coulteri & 3.29 & 3.18 & 5.06 & 3.84 \\
\hline Meliosma matudae & 2.63 & 3.18 & 4.68 & 3.50 \\
\hline Rondeletia ovandensis & 3.95 & 3.97 & 2.15 & $3 \cdot 36$ \\
\hline Bunchosia lanceolata & 2.63 & 3.18 & 4.25 & 3.35 \\
\hline Myriocarpa longipes & 2.63 & 2.38 & $4 \cdot 31$ & 3.11 \\
\hline Rubiaceae sp. & 3.95 & 3.97 & 1.40 & 3.10 \\
\hline Trophis chiapensis & 3.29 & 3.18 & 1.69 & 2.72 \\
\hline Saurauia kegeliana & 2.63 & 2.38 & 2.20 & 2.40 \\
\hline Cupania aff. macrophyila & 1.32 & 1.59 & $3 \cdot 44$ & 2.10 \\
\hline Ardisia siltepecana & 1.97 & 2.38 & 1.93 & 2.10 \\
\hline Lycianthes orogenes & 1.97 & 1.59 & 2.53 & 2.03 \\
\hline Casearia tacanensis & 1.32 & 1.59 & 2.59 & 1.83 \\
\hline Podocarpus matudae & 1.32 & 0.79 & 3.26 & 1.79 \\
\hline Malvaviscus lanceolatus & 1.97 & 2.38 & 0.94 & 1.76 \\
\hline Rondeletia intermedia & 1.32 & 1.59 & 1.80 & 1.57 \\
\hline Total for 20 species & 71.06 & 69.88 & 79.75 & 73.22 \\
\hline Other 34 species & 28.94 & 30.12 & 20.25 & 26.78 \\
\hline Total & 100.0 & 100.0 & 100.0 & 100.0 \\
\hline
\end{tabular}

Qualitative results Six main plant communities were identified along the El Triunfo trail; for each, its location, altitudinal range, major tree species components, and the presence of the Azure-rumped Tanager are summarized in Table 4; for detailed information on their species composition and physiognomic characteristics refer to Long and Heath (in press).

(i) Azure-rumped Tanager habitat. In Azure-rumped Tanager habitat along the El Triunfo trail on the Pacific slope between 1,050 and 1,700 m, 291 species of vascular plant of 89 families and 205 genera were recorded (see Appendix 1), of which 136 species were trees and 47 species shrubs (see Appendix 2). Notably several of the species found within the tanager's habitat are poorly collected, and some species were previously known only from a handful of specimens taken at Monte Ovando (Decachaeta ovandensis, Heisteria acuminata, Desmopsis lanceolata, Bunchosia matudae, Centardisia [Ardisia] ovandensis, Daphnopsis flavida, Plocaniophyllon flavum, Rondeletia ovandensis), the location of a past Azurerumped Tanager collection.

The habitat of the Azure-rumped Tanager is a medium height, broadleaf forest with the canopy extending to $25 \mathrm{~m}$ and occasional trees up to $35 \mathrm{~m}$ (Figures $3 \mathrm{a}$ and $b$ ). It is essentially an evergreen formation although a number of tree species shed their leaves towards the end of the dry season in February. However, the 


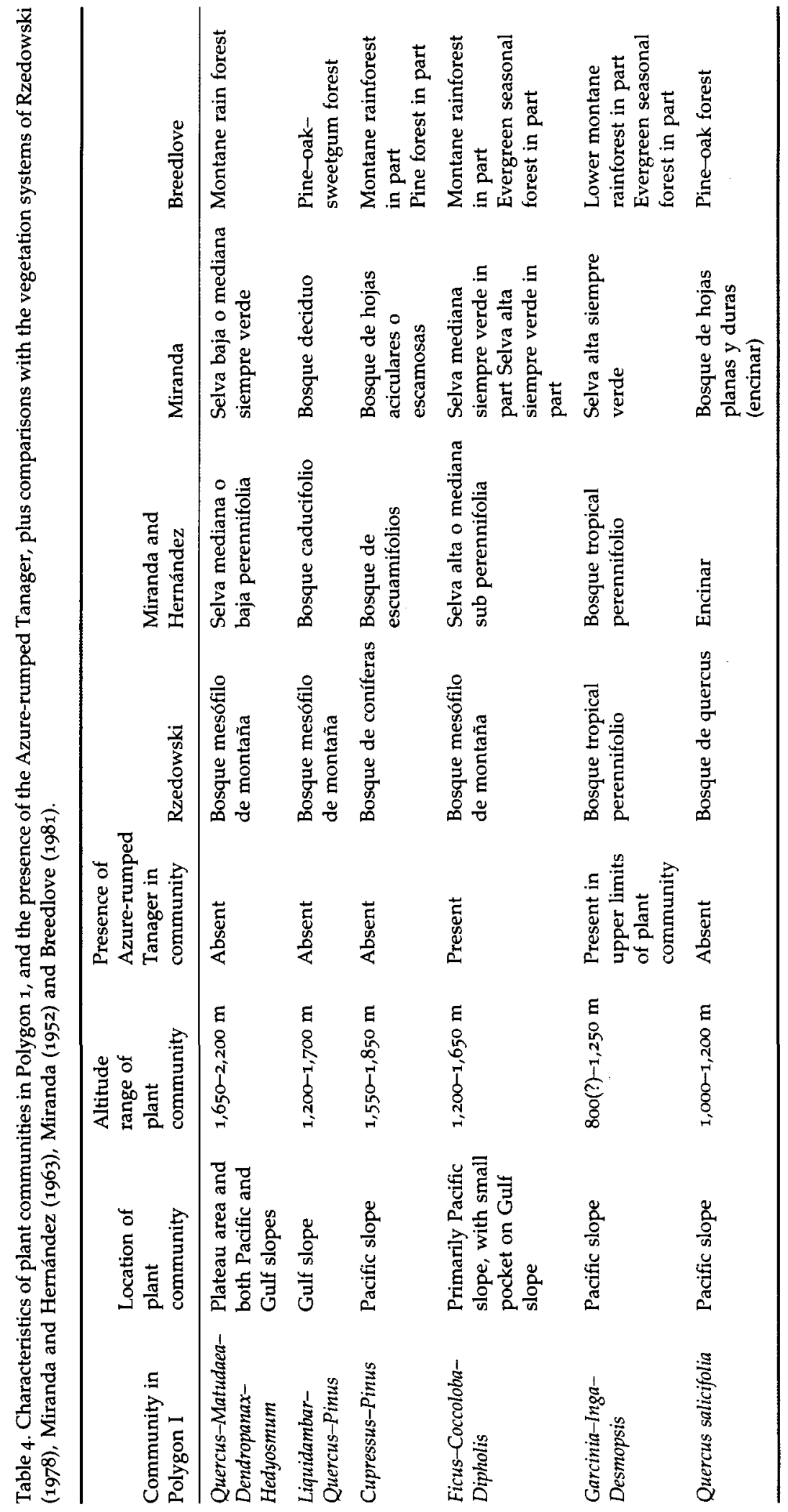




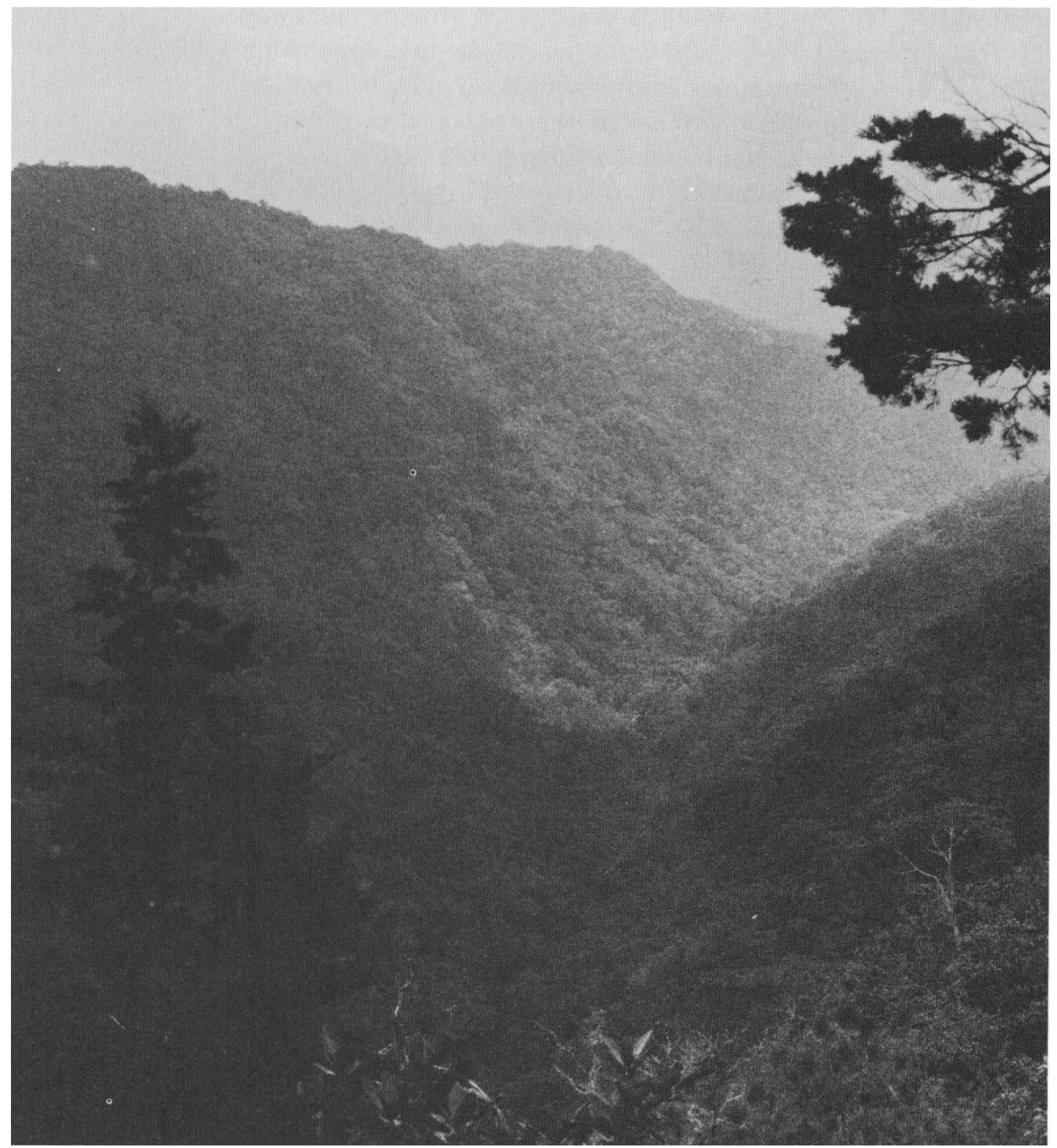

Figure 3a. Río Novillero valley, Pacific slope of the Sierra Madre de Chiapas.

period of leaf flushing is short, with the new leaves fully grown by late March. The canopy cover is complete but can appear open and discontinuous through natural disturbance to the forest. Tree falls are common and in the vicinity of Cañada Honda during 1989 there were two landslips, which opened up large (c. 2 ha) gaps in the vegetation.

The forest supports a well-developed understorey of small trees and shrubs, especially rich in species from the Rubiaceae, Compositae and Solanaceae. It contains a high density of Chamaedorea palms (C. elegans, $C$. aff. neurochlamys, $C$. aff. nubium). In rocky areas with thin soils and steep slopes, scandent species from the Araceae and Commelinaceae are common and, in wetter gullies, herbs including several species of Begonia and Achimenes abound. Epiphytes are prominant but are significantly less abundant than in the cloud-forest community 


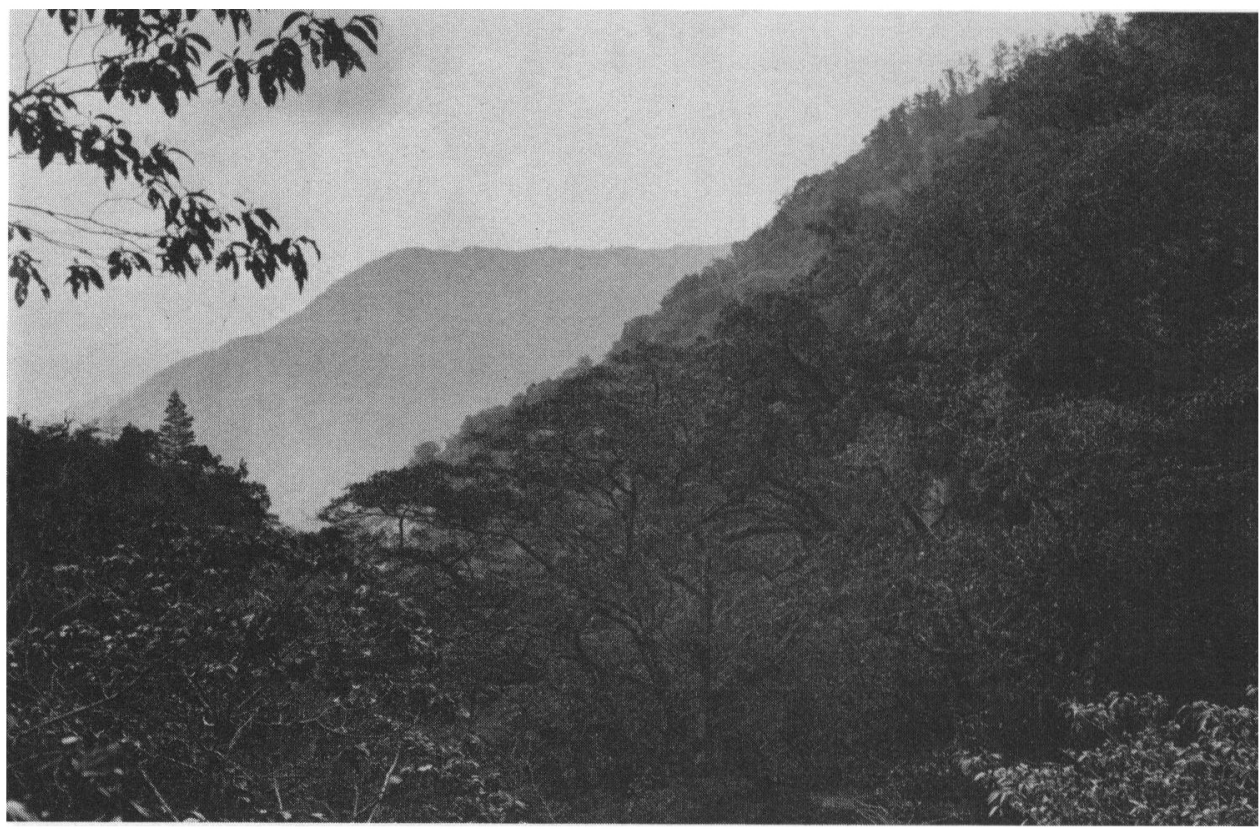

Figure 3b. Azure-rumped Tanager habitat along the El Triunfo trail at Cañada Honda.

above 1,700 $\mathrm{m}$ (see Non-tanager habitat). Mosses are sparse and are replaced by lichen which covers many of the trunks and branches.

(ii) Non-tanager habitat. Vegetation with similar species composition and physiognomic characteristics to the Azure-rumped Tanager habitat of the Pacific slope was found along the trail on the Gulf slope in secluded valleys with a humid but cool microclimate. However, along the trail on the Gulf slope, outside of these valleys, sweetgum-pine-oak forest is more widespread and forms the characteristic plant community between 1,200 and 1,700 $\mathrm{m}$. This community tends to be open and less diverse in tree species with sweetgum (Liquidambar styraciflua), pine (Pinus oocarpa var. ochoteranae) and oak (Quercus segoviensis, $Q$. acatangensis and Quercus spp.) the clear dominants.

At altitudes above $1,700 \mathrm{~m}$ the major vegetation community is a broadleaf evergreen mesophilous formation commonly referred to as cloud-forest (nubliselva or selva de neblina). This community is characterized by the wealth and abundance of epiphytic species. Trees are covered with many species of bromeliads, orchids, pteridophytes and mosses, the latter growing in dense mats on all available substrates. The understorey is dominated by several species of tree fern (Alsophila salvinii, Cyathea fulva and C. valdecrenata), this life-form being notably absent from Azure-rumped Tanager habitat. The main tree species include several oaks (Quercus aff. benthamii, Q. oocarpa, Q. sapotifolia and Quercus spp.), Matudaea trineroa, Dendropanax populifolius, Conostegia vulcanicola, Hedyosmum mexicanum and Symplococarpon flavifolium, none of which was found in the tanager's habitat.

Restricted to the ridges above $1,650 \mathrm{~m}$ on the Pacific slope along the El Triunfo 
trail is a forest dominated mainly by cypress (Cupressus benthamii var. lindleyi) and pine (Pinus oocarpa var. ochoteranae), with few other tree species present. The canopy is quite open and the cover of lower trees and shrubs variable. On the ridges at lower altitudes from 1,000 to $1,150 \mathrm{~m}$ is a forest supporting almost pure stands of Quercus salicifolia, and along ridges below $1,000 \mathrm{~m}$ in the vegetation is tropical deciduous forest, and canopy open from December until March.

The vegetation on the Pacific slope becomes noticeably more tropical with decreasing altitude. The forests below $1,000 \mathrm{~m}$ on the El Triunfo trail are medium height (up to $40 \mathrm{~m}$ ) and humid, especially in the valleys. They share physiognomic characteristics with Azure-rumped Tanager habitat, but the species composition is quite distinct and there is a lower density of epiphytes but more lianas.

(iii) The classification of vegetation types. Numerous vegetation classification systems exist for the Americas, Mexico and Chiapas, and they vary in their terminology. Table 4 relates the Azure-rumped Tanager habitat and other plant communities found along the El Triunfo trail to the most popular vegetation keys for Mexico (Miranda and Hernández 1963, Rzedowski 1978), and the two that exist solely for Chiapas state (Miranda 1952, Breedlove 1981). Using these, the Azure-rumped Tanager habitat is classified as selva alta o mediana sub perennifolia (medium or tall semi-evergreen forest: Miranda and Hernández 1963); bosque mesófilo de montaña (mesophilous montane forest: Rzedowski 1978); selva mediana siempre verde to selva alta siempre verde (medium to tall evergreen forest: Miranda 1952); and montane rainforest or evergreen seasonal forest (Breedlove 1981).

The tanager's habitat is difficult to place in a single category within a vegetation key because the forest composition contains species characteristic of both the mesophilous montane forests found higher up the mountain, and the tropical formations of the lower slopes and lowland areas. Tree species commonly associated with mesophilous montane forest and which are well represented in Azure-rumped Tanager habitat, include four from the Araliaceae family, and the genera Podocarpus, Billia, Meliosma and Phoebe. The shrub and small-tree understorey also contains various evergreen species from genera of the Acanthaceae (Aphelandra and Justicia), Rubiaceae (Deppea, Hoffmannia, Psychotria and Rondeletia) and Solanaceae (Cestrum, Lycianthes and Solanum). The forest, however, lacks the abundance of epiphytic mosses and orchids which are elements typical of mesophilous forest. Tree species present that are usually associated with tropical forests include Ficus cookii, Bursera simarouba and Sapium schippii, which also have significant importance values in the tanager habitat examined quantitatively (Table 2). Despite Azure-rumped Tanager habitat supporting characteristics of both mesophilous montane rainforest and tropical lowland forests, the majority of plant species listed were not found in the other six communities identified along the El Triunfo trail (see Table 4).

\section{The distribution of the Azure-rumped Tanager and its habitat in the Sierra Madre de Chiapas}

The distribution of the Azure-rumped Tanager and its habitat (as defined above) in the Sierra Madre de Chiapas was examined from field surveys and map 
analysis. Clearly it would have been worthwhile to have visited other localities with past records of the tanager but this was not possible due to the low budget of this project. However, the limited field visits made were complemented by a complete study of the region using the most detailed and recently published vegetation maps available. The protected areas in the Sierra Madre de Chiapas were also reviewed to assess the adequacy of protection of Azure-rumped Tanager habitat.

The extreme north-western portion of the Sierra Madre de Chiapas, from west of Cerro El Caracol $\left(16^{\circ} 19^{\prime} \mathrm{N} 93^{\circ} 41^{\prime} \mathrm{W}\right)$ to the Oaxaca border, was excluded from the surveys. This area is separated from the south-eastern part of the mountain chain by a natural land break at $1,000 \mathrm{~m}$ above sea level. The climate in the north-west shows a marked dry season and annual rainfall of less than $1,500 \mathrm{~mm}$ (Mülleried 1957). Correspondingly, this region is more arid than areas to the east, and the vegetation consists of tropical dry deciduous and pine forest formations (Miranda 1952, A. Hernández verbally 1990). Therefore it is considered highly unlikely that the Azure-rumped Tanager will be found in this section of the mountain range.

\section{Field surveys}

Surveys were carried out between February and April 1990. They were conducted on foot, although in some cases observations were made from a vehicle (when dismissing marginal areas containing habitat clearly unsuitable for the Azure-rumped Tanager). The visits covered small parts of the western, central and eastern sections of the Sierra Madre: the area of Cerro Tres Picos $\left(16^{\circ} 11^{\prime} \mathrm{N}\right.$ $93^{\circ} 37^{\prime} \mathrm{W}$ ) was selected in the western section of the sierra; several parts of the El Triunfo Biosphere Reserve were visited to assess the extent of habitat in this central region; and the area around Motozintla $\left(15^{\circ} 22^{\prime} \mathrm{N} 92^{\circ} 14^{\prime} \mathrm{W}\right)$ in south-east Chiapas bordering Guatemala was surveyed. In areas where the species was encountered a detailed description of the habitat was made using the same qualitative methodology employed on the El Triunfo trail. Additionally local people familiar with an area were interviewed to gather information concerning land tenancy, land use and the location of intact forest.

Azure-rumped Tanager sightings The Azure-rumped Tanager was found at few of the areas visited, and neither the western (Cerro Tres Picos) nor eastern (Motozintla) sections of the Sierra Madre: all sightings came from within the El Triunfo Biosphere Reserve in the central part of the mountain range. On the Gulf slope of this section it was observed at two localities, importantly representing the first records for the species on this escarpment. These were south of Ejido Santa Rita $\left(15^{\circ} 41^{\prime} \mathrm{N} 92^{\circ} 48^{\prime} \mathrm{W}\right)$ at $1,450 \mathrm{~m}$, and Finca El Porvenir $\left(15^{\circ} 42^{\prime} \mathrm{N}\right.$ $92^{\circ} 58^{\prime} \mathrm{W}$ ) above Finca Custepec at 1,400 to $1,600 \mathrm{~m}$. On the Pacific slope the Azure-rumped Tanager was also sighted at two localities. These were along the path between Palo Gordo and Loma Bonita $\left(15^{\circ} 39^{\prime} \mathrm{N} 92^{\circ} 51^{\prime} \mathrm{W}\right)$ at $1,200 \mathrm{~m}$, and above Ejido San Antonio Miramar $\left(15^{\circ} 40^{\prime} \mathrm{N} 92^{\circ} 59^{\prime} \mathrm{W}\right)$ on the path to Finca Custepec between 1,100 and $1,400 \mathrm{~m}(8 \mathrm{~km}$ and $30 \mathrm{~km}$ west respectively of Cañada Honda).

All the tanager sightings were in forest similar in structure and species com- 
position to Azure-rumped Tanager habitat identified on the Pacific slope along the El Triunfo trail. However, at both sites on the Gulf slope, the species's habitat contained a higher presence of sweetgum and was restricted to valleys which were generally humid and sheltered. Outside of these valleys sweetgumpine-oak forest was dominant and the tanager was never seen.

Above Finca El Porvenir and San Antonio Miramar sightings came from forest edge, partially degraded forest, and intact interior forest. At El Porvenir the forest borders extensive coffee plantations but the Azure-rumped Tanager was never seen in this habitat, despite the presence of shade trees. At San Antonio Miramar, coffee-growing is less intensive and there exists a mixture of intact forest, small fields of coffee bushes, scrub and more open degraded forest. On two occasions, small groups of Azure-rumped Tanagers were seen in degraded forest edge, but the birds soon returned to the adjacent intact forest.

Localities with no tanager sightings The Gulf slope of Cerro Tres Picos was the most north-westerly region visited. The Pacific slope of this mountain was not surveyed (although from past tanager sightings this slope should be more likely to hold the species) as access is extremely difficult from the nearest settlement. The Gulf slope of the mountain below 1,200 m supports open pine forest, which has been extensively degraded through wood extraction and grazing. The forest between $1,200 \mathrm{~m}$ and 1,700 $\mathrm{m}$ is in excellent condition, dominated by sweetgumpine-oak, with some sweetgum reaching $50 \mathrm{~m}$ in height, but Azure-rumped Tanagers were not seen during two days spent between 1,200 and 1,800 $\mathrm{m}$ on this slope. Forest in small stream valleys was structurally similar to known tanager habitat but the species composition was distinct. For instance, the understorey species assemblage typical of tanager habitat was totally different, with Mollinedia pallida, Croton reflexifolius, Trophis chiapensis, Meliosma matudae, Rondeletia ovandensis and Casearia tacanensis absent.

In the south-east of the mountain chain in the vicinity of Motozintla at lower altitudes of between 500 and 1,200 $\mathrm{m}$ on the Gulf slope along the river Grijalva valley, tropical deciduous forest was common. Open pine associations, which were unsuitable habitat for the tanager, dominated above $1,300 \mathrm{~m}$. Above $1,700 \mathrm{~m}$ evergreen broadleaf forest predominated, similar in structure to the Quercus-Matudaea-Dendropanax-Hedyosmum community found at El Triunfo, with a high abundance of epiphytes and tree ferns in the understorey. Much of the land visited near to Motozintla on the Pacific slope road to Huixtla was under coffee cultivation. The few remnant patches of forest consisted of broadleaf associations, but these were few in number and, in drier parts, pine-oak and deciduous forest (with cacti) predominated.

\section{Map analysis}

Vegetation maps of scale 1:250,00o published by the Instituto Nacional de Estadística, Geografía y Informática (INEGI) were used and two maps cover the region: Tuxtla Gutiérrez E15-11 and Huixtla D15-2. To produce these maps, INEGI combined information derived principally from aerial photographs and field surveys with older maps and regional literature (INEGI 1986). The altitudinal range of the Azure-rumped Tanager was taken to be between 1,000 
and 1,700 $\mathrm{m}$, which covers all certain records of the species, including our own. INEGI identify nine vegetation and land-use categories for land within this altitudinal band. The categories are: selva alta perennifolia, tall evergreen tropical forest; bosque mesófilo de montaña, mesophilous montane forest; selva baja caducifolia, low tropical deciduous forest; bosque de pino-encino, pine-oak forest; bosque de encino-pino, oak-pine forest; bosque de pino, pine forest; bosque mediana subcaducifolia, medium-height tropical semideciduous forest; pastizal inducido, pasture; and agricultura de temporal, temporary agriculture.

Caution was exercised in the interpretation of the information given by these maps. Unfortunately, neither on the maps nor in the accompanying guidebook does INEGI (1986) state the vegetation classification system followed in their compilation. The species composition listed on the maps for certain groundtruthed survey points appears to conform mainly to the classification system of Miranda and Hernández (1973), but also contains elements from Rzedowski (1978). Moreover, as few field surveys were made by INEGI in the Sierra Madre mountains, the information on vegetation for this region seems likely to have been derived extensively from aerial photographs. This is cause for further caution for, while some forest types are distinct and easily recognizable from aerial photographs, others, sharing similar heights and structures but with different species composition, appear homogeneous. Broadleaf forests and pine associations (pine, pine-oak, oak-pine) are easily identifiable and separable. Deciduous forests are apparent when the canopy species have shed their leaves during the winter, but can be difficult to distinguish from broadleaf evergreen forests at other times of the year. Agricultural and cultivated lands are normally visible on aerial photographs although small patches, especially of coffee, can be difficult to discern amongst broadleaf forest.

Because of these shortcomings of the INEGI maps, the nine vegetation types shown on the maps were combined in this study into four categories that can be distinguished from aerial photographs. These are: (1) pine forest associations (pine, pine-oak and oak-pine forests); (2) evergreen broadleaf forest associations (tall evergreen tropical forest, mesophilous montane forest and mediumheight tropical semideciduous forest); (3) deciduous forest (low tropical deciduous forest); and (4) agriculture or pasture. In order to map the extent and distribution of these four categories in the tanager's altitudinal range, the 1,000 to $1,700 \mathrm{~m}$ contours and intervening vegetation categories were digitized using a GIS package (PC ARC/INFO). The information was "read" using an electronic pen which transmits precise coordinates to a computer. All area calculations performed using the ARC/INFO package were made by transforming the digitized maps to equal-area projections.

Extent and area of the four vegetation categories The total area in hectares was calculated for each of the four land-use categories and their distributions are shown in Figure 4 a-e. A total of 381,500 ha is found within the map survey limits of which 158 , 00o ha $(41 \%)$ is evergreen broadleaf forest, 129 , ooo ha $(34 \%)$ pine forest associations, 77,00o ha (20.5\%) agricultural land and 16,500 ha (4.5\%) deciduous broadleaf forest. There are clear patterns in their respective distributions with pine associations restricted mostly to the Gulf slope and evergreen broadleaf forest more widespread on the Pacific slope. Comparatively little 
Figure 4. The central and southern portion of the Sierra Madre de Chiapas mountain range. The black shading in the following five maps represents, respectively, (a) land between 1,000 and $1,700 \mathrm{~m}$ covered by the map analysis; $(b)$ evergreen broadleaf forests; $(c)$ pine forests; $(d)$ deciduous broadleaf forests; $(e)$ agriculture.

(a)

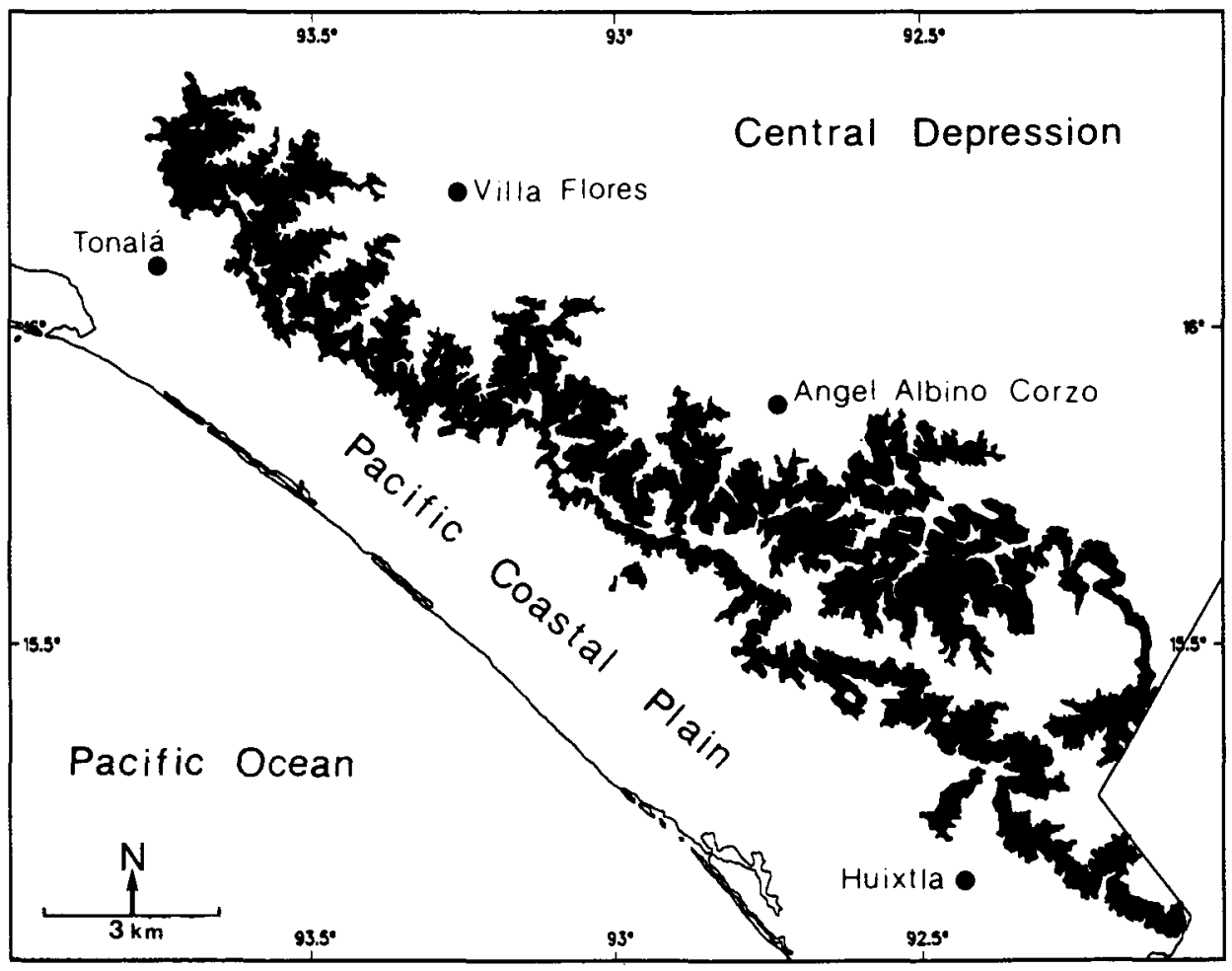

(b)

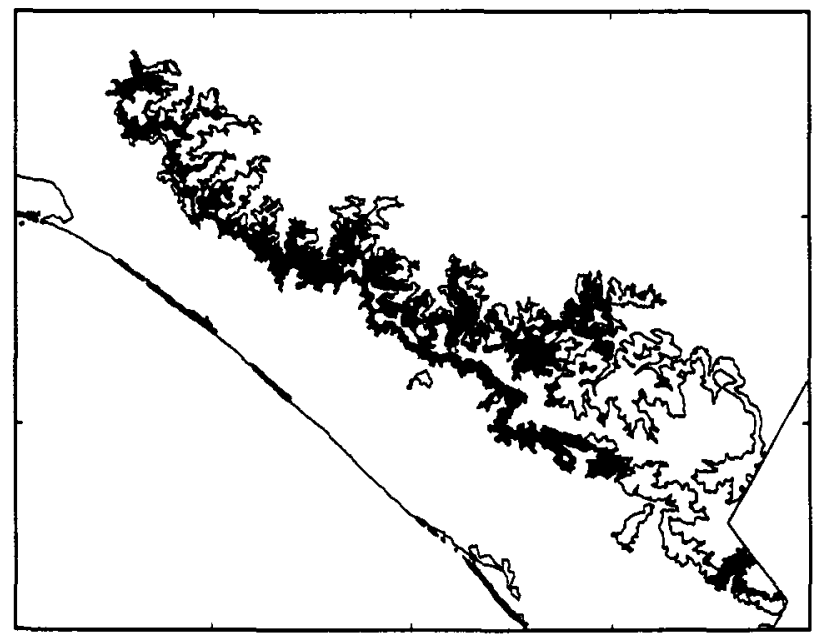


(c)

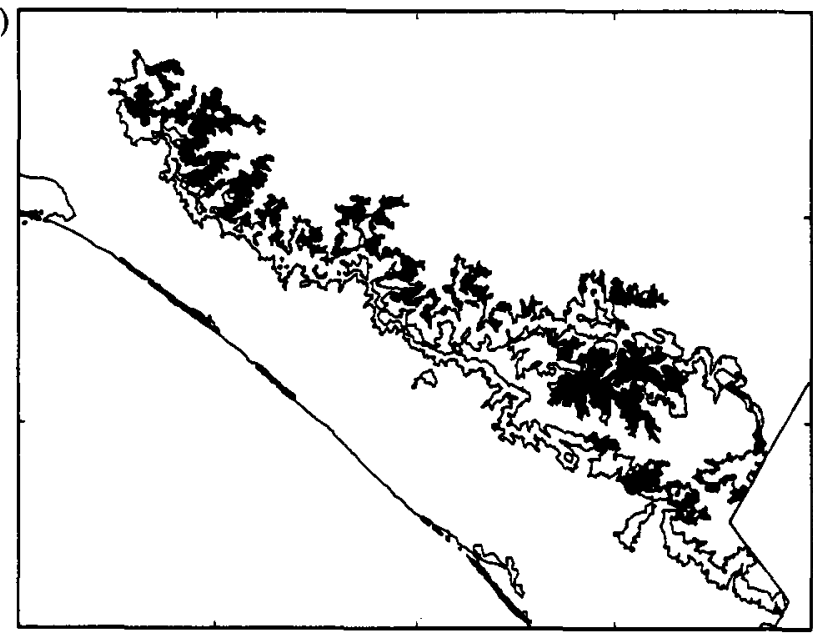

(d)

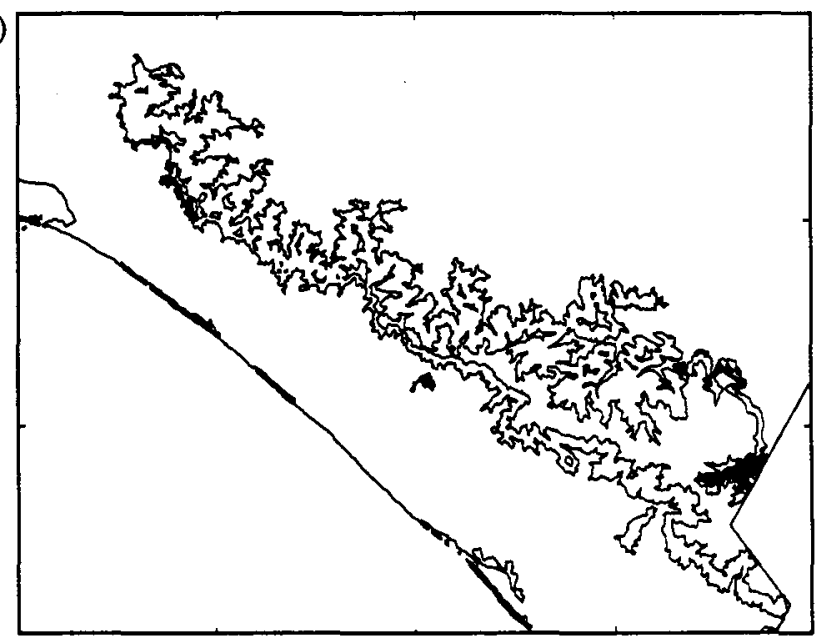

(e)

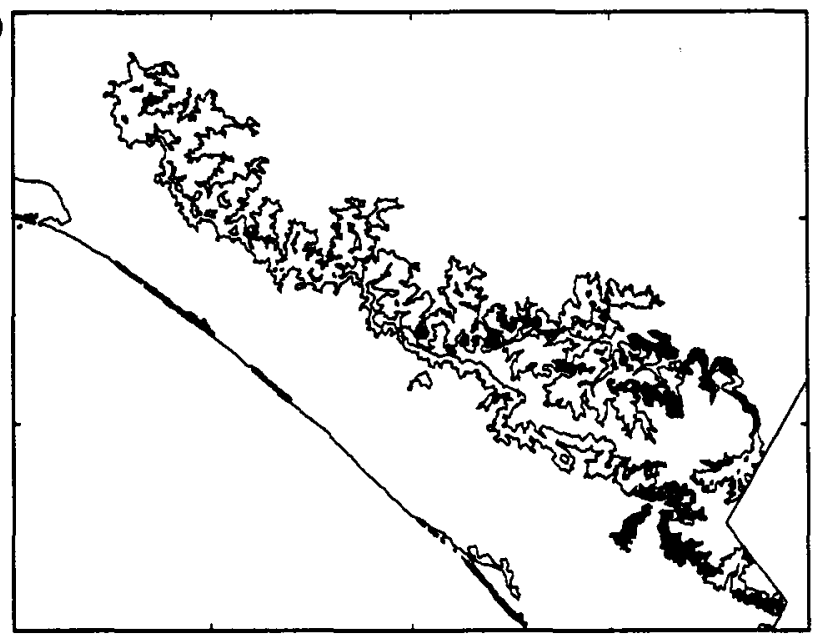


deciduous forest exists within the survey area limits and agricultural land is scattered throughout, with greater extensions under cultivation in the east than the west.

The habitat study and the broader field surveys show that only the evergreen broadleaf forest category holds potential habitat for the Azure-rumped Tanager. However, this category comprises vegetation types (and plant communities) which are not all suitable Azure-rumped Tanager habitat. Therefore we divided the evergreen broadleaf forest into three categories (Figure 5): probable Azurerumped Tanager habitat; possible tanager habitat; and non-tanager habitat (sweetgum-pine-oak forest). Our judgement in making these divisions was based on (a) vegetation information from field visits, (b) discussions with local people in the Sierra Madre de Chiapas and wardens of the El Triunfo Reserve familiar with areas not surveyed in this study, and (c) Miranda (1952, 1957) and Breedlove (1981). The areas of probable and possible tanager habitat are 59,268 ha and 53,257 ha respectively, giving a maximum potential (probable and possible summed) of 112,525 ha of Azure-rumped Tanager habitat in the Sierra Madre de Chiapas.

Protected areas in the Sierra Madre de Chiapas Two decreed and three proposed reserves of varying categories are situated within the Sierra Madre survey area,

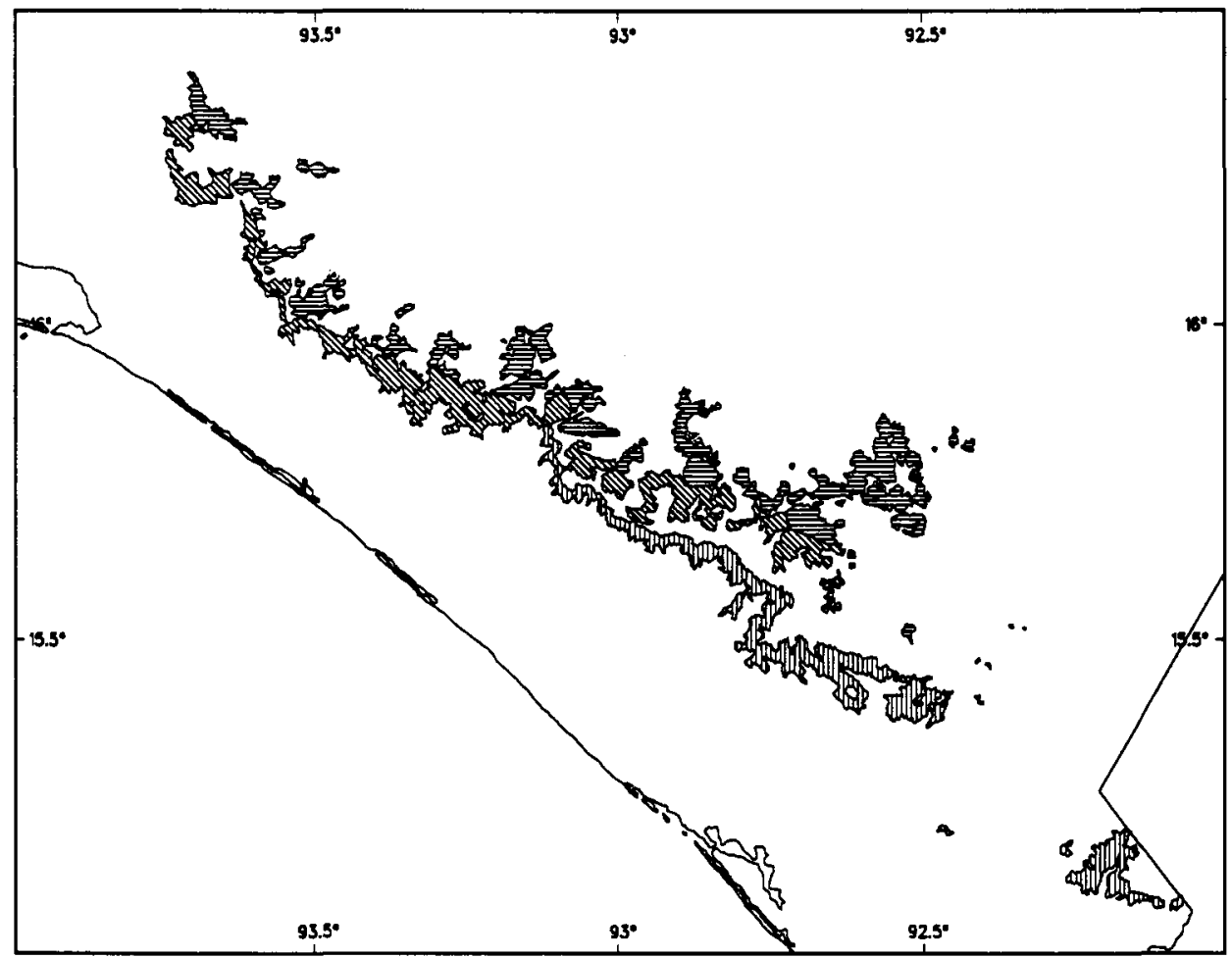

Figure 5. The distribution of probable Azure-rumped Tanager habitat (vertical hatching), possible Azure-rumped Tanager habitat (cross hatching) and sweetgum-pine-oak forest (horizontal hatching) within the region covered by the map analysis. 
Table 5. Decreed and proposed reserves in the Sierra Madre de Chiapas.

\begin{tabular}{lcl}
\hline Reserve & Area (ha) & Status \\
\hline La Sepultura & 73,800 & No decree \\
Ecological Reserve & & No protection status \\
La Frailescana & 60,450 & Presidential decree \\
Forestry Reserve & & 3 January 1978 \\
El Triunfo & $\mathbf{1 1 9 , 1 7 7}$ & Presidential decree \\
Biosphere Reserve & & 13 March 1990 \\
Pico el Loro-Paxtal & 15,000 & No decree \\
Cloud-forest Reserve & & No protection status \\
Volcán Tacaná & $<10,000$ & No decree \\
& & No protection status \\
\hline
\end{tabular}

and their characteristics are summarized in Table 5. Part of the El Triunfo Biosphere Reserve, namely the 10,000 ha around the El Triunfo camp, has been an Ecological State Reserve since 1972. Through the work of the Instituto de Historia Natural de Chiapas (IHN), a state government organization, this reserve was enlarged and received biosphere status in 1990. The total area of the reserve $(119,000 \mathrm{ha})$ is comprised of five separate polygons or core areas, totalling 30,00o ha, which are encompassed within a more extensive buffer zone. El Triunfo is jointly managed by IHN and the Secretaría de Desarollo Urbano y Ecología (SEDUE), a department of the federal government, with four wardens stationed at the El Triunfo camp in Polygon 1 and more than 15 people (based at IHN in Tuxtla Gutiérrez) involved with the management and administration of the reserve.

La Frailescana, situated to the west of El Triunfo, is the only other decreed reserve in the region. It is a forest reserve established to monitor the extraction of timber from the area and was controlled by the Secretaria Agricultura y Recursos Hydráulicas (SARH). Recently the local division responsible for its management was disbanded and currently this reserve does not afford any degree of protection to the forest it contains. Meanwhile IHN is working towards the establishment of a reserve at La Sepultura to protect the most westerly portion of the Sierra Madre de Chiapas bordering Oaxaca state, but most of the land in this proposed reserve is outside the range of the Azure-rumped Tanager. Two more proposed reserves, Volcán Tacaná and Pico de Loro Paxtal, are located to the east of El Triunfo; however, there have been no further developments in these areas since the proposals were made, indicating that their establishment and protection, at least in the near future, is unlikely.

The El Triunfo Biosphere Reserve is thus the only reserve that affords any degree of protection to the forests of the Sierra Madre de Chiapas. To calculate how much potential tanager habitat is contained within it, the reserve boundaries and polygon limits were digitized and overlaid onto a digitized vegetation map of probable and possible Azure-rumped Tanager habitat. The results are shown in Figure $6 a$ and $b$, and Table 6 gives the calculated areas of probable and possible tanager habitat found within each part of the reserve. Probable and possible Azure-rumped Tanager habitat accounts for some $37 \%$ of the total area of El Triunfo, but only $21 \%$ of this is found within the core areas. 

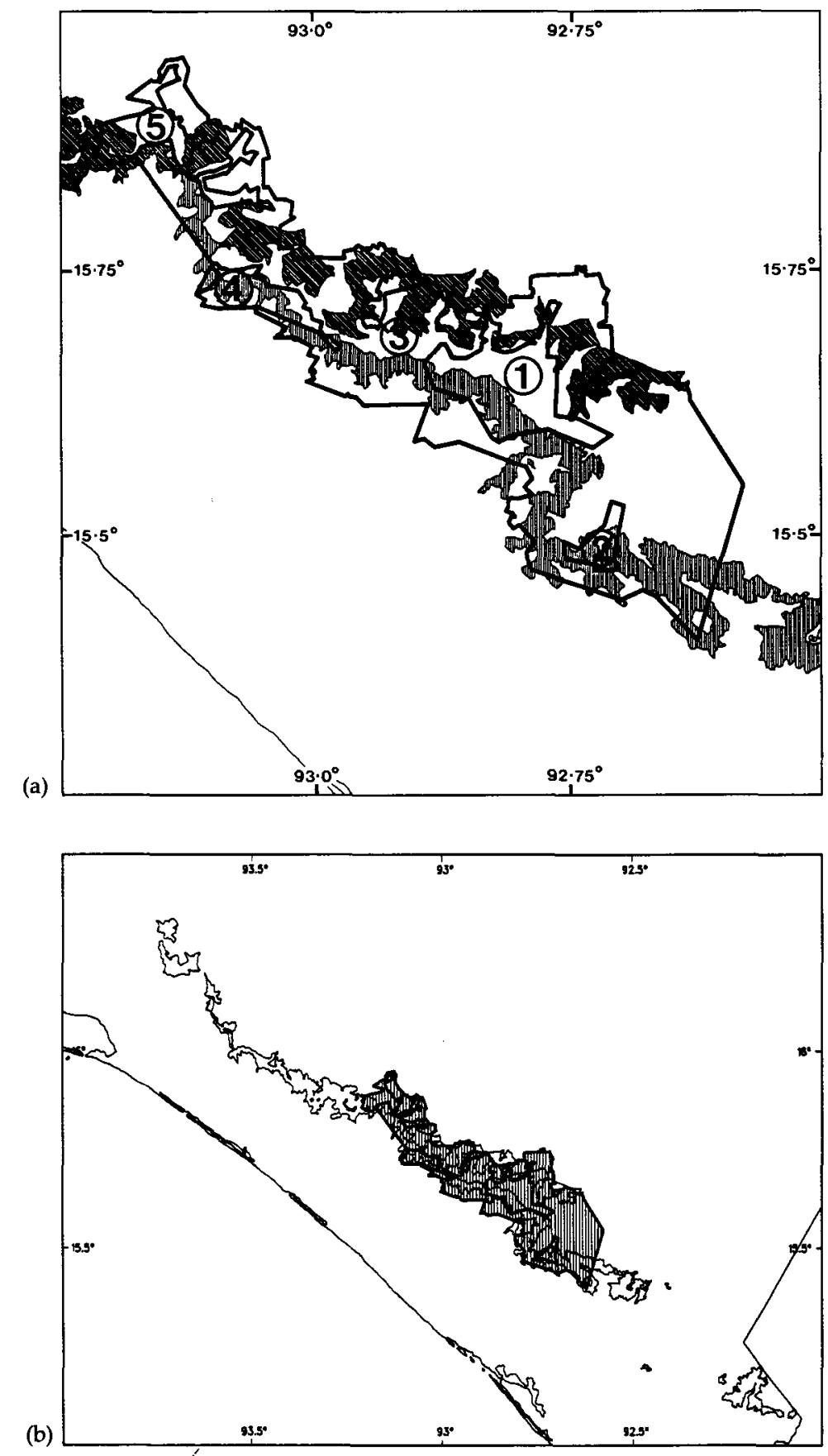

Figure 6. The El Triunfo Biosphere Reserve and Azure-rumped Tanager habitat. (a) The distribution of probable (vertical hatching) and possible (cross hatching) Azure-rumped Tanager habitat in the El Triunfo Biosphere Reserve. The numbers correspond to the polygons (core areas) of the reserve. 1, El Triunfo; 2, Monte Ovando; 3, Custepec; 4, El Venado; 5, La Angostura. (b) The location of El Triunfo (vertical hatching) in relation to the distribution of potential (probable and possible) Azure-rumped Tanager habitat. 
Table 6. Quantitative breakdown of possible and probable Azure-rumped Tanager habitat (in hectares) for land (protected and unprotected) in the Sierra Madre de Chiapas.

\begin{tabular}{|c|c|c|c|}
\hline & \multicolumn{3}{|c|}{ Azure-rumped Tanager habitat } \\
\hline & Probable & Possible & $\begin{array}{l}\text { Probable and possible } \\
\text { (potential) }\end{array}$ \\
\hline \multicolumn{4}{|l|}{ El Triunfo Reserve } \\
\hline Polygon 1 & 3,312 & 273 & 3,585 \\
\hline 2 & 1,272 & & 1,272 \\
\hline 3 & & 455 & 455 \\
\hline 4 & 1,972 & & 1,972 \\
\hline 5 & & 1,769 & 1,769 \\
\hline Total polygons & 6,557 & 2,497 & 9,054 \\
\hline Buffer zone & 17,239 & 17,367 & 34,606 \\
\hline Total El Triunfo Reserve & 23,769 & 19,864 & 43,660 \\
\hline Outside El Triunfo & 35,599 & 33.393 & 68,992 \\
\hline Total area & 59,268 & 53,257 & 112,525 \\
\hline
\end{tabular}

The core (polygon) zones are the only areas which afford full protection to the forests as, unless the presidential decree is flaunted, no habitat destruction or permanent habitation can take place within them. The surrounding buffer zone is designed to give added protection to the core areas but to permit a restricted amount of land use. The buffer zone of El Triunfo encompasses 68 ejido communities and 235 privately owned properties (IHN 1988). Land currently under cultivation consists mainly of coffee, including large plantations such as fincas and smaller areas in ranchos or ejido communities. The human population density in the buffer zone is low, many of the ejidos having formed within the past 15 years, and most living between 500 and $1,200 \mathrm{~m}$. As a direct consequence of this small population, large tracts of pristine forest, including probable and possible tanager habitat, still exist in the buffer zone and connect the forests within the five core areas.

\section{Discussion}

\section{The Azure-rumped Tanager in the Sierra Madre de Chiapas}

In Chiapas the Azure-rumped Tanager is primarily distributed along the Pacific slope of the Sierra Madre. The species also occurs on the Gulf slope but it seems that this is only the case in regions where the mountain spine is relatively narrow with a short distance between the Pacific and Gulf escarpments. Under such conditions the floristic composition of the vegetation in the humid valleys on the Gulf slope between 1,200 and 1,600 $\mathrm{m}$ is very similar to tanager habitat on the Pacific slope. The Azure-rumped Tanager should therefore occur in other Gulf slope areas of the central part of the mountain range where these conditions prevail. Further east along the mountain chain the distance between the two escarpments increases, and this reduces the similarities in vegetation between the two slopes. In the eastern part of the Sierra Madre large areas of 
pine associations dominate the Gulf slope, whilst the Pacific slope supports evergreen broadleaf forest (see Figure $4 a$ and b), and consequently the Azurerumped Tanager is almost certainly restricted to the Pacific slope.

In the west of the Sierra Madre climate is probably the important factor determining the distribution of the Azure-rumped Tanager. The north-western region of the mountains has less annual rainfall and a longer dry season than areas further east, and this affects the composition of the vegetation communities present. Azure-rumped Tanager habitat is humid throughout the year with only a very short dry period, and it is probably limited to areas with annual rainfall above $2,000 \mathrm{~mm}$. However, there is insufficient information available to evaluate exactly where the climatic changes which cause increasing aridity moving westwards will limit the distribution of the species's habitat in the area covered by the map analysis. Miranda (1957) states that broadleaf evergreen formations below 1,200 $\mathrm{m}$ on the Pacific slope peter out slowly west of $93^{\circ} 30^{\prime} \mathrm{W}$, but unfortunately does not describe the vegetation types found higher up the slopes which are more relevant to the tanager's habitat.

The plant species composition of the forests occurring below $1,000 \mathrm{~m}$ on the Pacific slope are distinct from known Azure-rumped Tanager habitat, but it remains possible that they support the tanager. The forests share some physiognomic characteristics and certain species such as Ficus cookii (the dominant tree species in the tanager habitat sampled) also occur. If the tanager is found lower in altitude, we predict that it will probably be restricted to the humid river valleys where tree species characteristic of its habitat are more common. On the other hand, it seems likely that $1,700 \mathrm{~m}$ is a genuine upper limit for the species, because this altitude also marks the upper limit of the tropical elements of the vegetation which are characteristic components of the tanager's habitat at all known localities. Although Azure-rumped Tanager habitat contains plant species typical of higher-altitude forests, it is physiognomically very distinct from these formations.

The Azure-rumped Tanager was seen at forest edges and areas where limited human activities had degraded the forest, but never in clearings or coffee plantations. Nevertheless, Hilty and Simon (1977) infer that it and other species may benefit from the increases in food provided by shrubs which predominate in cleared areas. Our observations suggest, however, that the Azure-rumped Tanager is not a species which frequently uses fruiting shrubs in cleared areas: despite on occasions being more visible in open patches or forest edge, it was seen more often foraging in pristine forest.

\section{Threats to the Azure-rumped Tanager}

The major threat to the Azure-rumped Tanager is habitat destruction. This is a serious problem because the altitudinal range of the species coincides with the optimal land for coffee cultivation. Coffee is the principal Chiapan contribution to the Mexican gross national product and exporting capacity, growing more than one-third of Mexico's coffee (Alvarez 1988). Since the turn of the century, the primary centre for coffee production in Chiapas has been the Pacific slope of the Sierra Madre, from the frontier with Guatemala to about $100 \mathrm{~km}$ into Chiapas (Soconusco region), and the region's development has resulted in the disap- 
pearance of much of the species's habitat in the area. Other large, well established and nationally important coffee plantations (e.g. Fincas Prusia and Custepec) are found along the main river valleys in the central portion of the mountain chain on the Gulf slope. Overall habitat destruction has resulted in the loss of more than $15 \%$ of the Azure-rumped Tanager's probable total range, but it is possible that this figure is actually higher since the available maps used do not present accurate information on forest that is partially degraded or small patches of agriculture created by subsistence farmers.

The expansion of agriculture, especially coffee, is continuing to increase in the Sierra Madre, and recently this has been due to new peasant communities, or "ejidos", that have formed in the mountains. Under Mexican federal law, any land that is national territory and not officially protected or being used can be leased out to a group of families to live from. In the Sierra Madre, some communites with less than 30 adults have been granted large parcels of land (often greater than 5,00o ha). Usually much of the land remains forested but clearance for cultivation quickly begins as farming is the major source of food and income.

\section{Status of the Azure-rumped Tanager}

The only protection for the Azure-rumped Tanager in Chiapas is the El Triunfo Biosphere Reserve, but it contains as much as $39 \%$ of the total probable and possible habitat of the species in the state. The effective protection and future status of the species rests strongly on the conservation of its habitat within El Triunfo and essentially this depends on collaboration in favour of conservation between the local people of the buffer zone and the IHN staff. Clearly, the human population in the reserve will increase and gradually place more pressure on land, and therefore habitat destruction is inevitable unless viable alternatives can be provided that are less damaging to the forest ecosystem. There is little information available on the status and use of the forest by the local people within the extensive boundaries of the El Triunfo Biosphere Reserve, as the IHN has concentrated its management efforts in and around Polygon 1 and consequently this core area is well protected and a good management infrastructure exists. The reserve management proposals state that forest vigilance and relations with local people will be developed in other parts of the reserve, although currently the protection of these areas is inadequate.

In its preferred habitat, the Azure-rumped Tanager was quite common and generally located quickly. However the extent of this habitat in Chiapas is very small, being less than $1,300 \mathrm{~km}^{2}$ (although it has always probably been less than $2,000 \mathrm{~km}^{2}$ ) and many parts, especially at lower elevations, are at risk of clearance for subsistence farming and coffee cultivation. There are still large gaps in our knowledge of the tanager's range as this study has not identified the western limit of the species's distribution, and in Guatemala the species is known from few sightings and is described as the country's least known and understood species (P. Rockstroh in litt. to N. J. Collar 1988). It is recommended that more surveys for the Azure-rumped Tanager are carried out in Chiapas and Guatemala and the present Red Data Book status of "Indeterminate" be changed to "Rare". If the species is shown to be in serious decline through accelerated habitat destruction it should be moved into the "Vulnerable" category. 


\section{Acknowledgements}

We carried out this project whilst in receipt of scholarships from the Consejo Nacional de Ciencias y Tecnología (CONACYT), under the Anglo-Mexican Cultural Exchange Programme, and were based at the Instituto de Historia Natural (IHN) in Chiapas. We thank Ramón Pérez Gil, former Assistant Director of IHN, the staff of the El Triunfo Project, the Natural Protected Areas Department and the Botany Department. We are also indebted to the wardens of the El Triunfo Biosphere Reserve for sharing with us their knowledge of the area and for their help during the fieldwork. The Percy Sladen Memorial Fund supported the fieldwork with a grant of $£_{4} 00$. We are grateful to the staff, especially Dr Fernando Chiang, of the National Herbarium at UNAM for help in plant identification. We thank Greg Lasley, Bret Whitney and Chris Leahy for their kindness in supplying unpublished notes on the Azure-rumped Tanager and Dr Brian Lavercombe of the British Council for his assistance in transporting our work back to England. We express our special thanks to Mike Adam, GIS Officer at the World Conservation Monitoring Centre, for his expertise in the preparation of the maps; also to David Wege for his useful comments on an earlier draft and Dr Nigel Collar for his advice and editorial work.

Appendix 1. Quantitative breakdown of the plants collected in Azure-rumped Tanager habitat along the Pacific slope of the El Triunfo trail between 1,050 and $1,700 \mathrm{~m}$.

\begin{tabular}{lccc}
\hline & Family & Genera & Species \\
\hline Pteridophyta & 6 & 9 & 12 \\
Gymnospermae & 1 & 1 & 1 \\
Dicotyledoneae & 72 & 167 & 235 \\
Monocotyledoneae & 10 & 28 & 43 \\
Total & 89 & 205 & 291 \\
\hline
\end{tabular}

\section{Appendix 2. List of trees and shrubs found in Azure-rumped Tanager habitat along the El Triunfo trail.}

Key to symbols: $\square$ species sampled in quantitative study in size-class $>12 \mathrm{~cm} \mathrm{DBH}$; species sampled in quantitative study in size-class 6-12 cm DBH; [s] shrub $<3 \mathrm{~m}$ tall.

\section{Acanthaceae}

Aphelandra schiedeana C. \& S. [s]

Justicia inaequalis Benth. [s]

Odontonema glabrum Brandegee [s] •

Ruellia matagalpae Lindau [s]

Actinidiaceae

Saurauia kegeliana Schlecht.

S. madrensis B.T. Keller \& Breedlove

Amaranthaceae

Iresine celosia L. [s]

Annonaceae

Desmopsis lanceolata Lundell •

Rollinia jimenezii Standley 
Appendix 2. (cont.)

Key to symbols: $\square$ species sampled in quantitative study in size-class $>12 \mathrm{~cm} \mathrm{DBH}$; species sampled in quantitative study in size-class 6-12 cm DBH; [s] shrub $<3 \mathrm{~m}$ tall.

\section{Apocynaceae}

Stemmadenia galeottiana (A. Rich) Miers

Tonduzia longifolia (A. DC.) Woodson.

\section{Aquifoliaceae}

Ilex quercetorum I.M. Johnston

\section{Araliaceae}

Dendropanax pallidus M. \& J. Cannon •

Oreopanax peltatus Linden ex Regel

$O$. sanderianus Hemsley

O. xalapensis (H.B.K.) Decne. \& Planchon

Aristolochiaceae

Aristolochia sp.

Boraginaceae

Tournefortia glabra $\mathrm{L}$.

Burseraceae

Bursera simaruba (L.) Sarg.

Capparaceae

Forchhammeria matudae Lundell

Caprifoliaceae

Viburnum hartwegii Benth.

\section{Celastraceae}

Maytenus sp.

Rhacoma riparia Lundell vel aff.

Zinowiewa matudae Lundell

Clethraceae

Clethra hartwegii Britton

C. obliquinervia Standley

C. suaveolens Turcz.

\section{Clusiaceae}

Clusia guatemalensis Hemsley

C. salvinii J.D. Smith

\section{Compositae}

Ageratina atrocordata (B. Rob.) King \& Rob.

Decachaeta ovandensis (Grashoff \& Beaman) King \& H. Rob.

Desmanthodium perfoliatum Benth.

Fleischmanniopsis leucocephala (Benth.) King \& H. Rob. [s]

Koanophyllon coulteri (B. Rob.) King \& H. Rob. [s]

K. pittieri (Klatt.) King \& H. Rob.

Senecio grandifolius Less.

Verbesina turbacensis H.B.K.

Vernonia arborescens (L.) Sw.

$V$. patens Kunth. [s]

Elaeocarpaceae

Sloanea ampla I.M. Johnston 


\section{Euphorbiaceae}

Acalypha firmula Muell. Arg. vel aff. [s]

A. macrostachyoides Muell. Arg. [s]

Croton reflexifolius H.B.K.

C. xalapensis H.B.K.

Euphorbia scabrella Boiss. [s]

Sapium schippii Croizat

\section{Fabaceae}

Cojoba donnell-smithii Britton \& Rose

C. escuintlensis L. Rico ined.

C. matudae (Lundell) L. Rico

Desmodium helleri Benth. ex Hemsley [s]

Desmodium sp. [s]

Inga calderonii Standley

I. endlicheri (Kuntze) MacBride

Mimosa albida H. \& B. ex Willd. IsI

Platymiscium pinnatum (Jacq.) Dug.

Zapoteca portoricensis (Jacq.) H. Hern. ssp. portoricensis

\section{Fagaceae}

Quercus skinneri Benth.

\section{Flacourtiaceae}

Casearia corymbosa H.B.K.

C. tacanensis Lundell $\bullet \bullet$

Lunania mexicana Brandegee [s]

Xylosma quichense J.D. Smith [s]

Gentianaceae

Lisianthius sp. [s]

Gesneriaceae

Achimenes pedunculata Benth. [s]

Moussonia fruticosa (Brandegee) T.S. [s]

Moussonia sp. [s]

Hippocastanaceae

Billia columbiana Planchon \& Linden

Juglandaceae

Alfaroa mexicana Stone vel aff.

Lauraceae

Lauraceae sp.

Nectandra coriacea (Sw.) Griseb.

N. reticulata (R. \& P.) Mez

N. sinuata $\mathrm{Mez} \square \bullet$

Persea americana L.

P. liebmannii Mez

Phoebe chiapensis Lundell

P. mexicana Meissn.

$P$. trinerois Lundell

$P$. trinervis Lundell vel aff.

\section{Loganiaceae}

Buddleia americana L.

\section{Lythraceae}

Cuphea ignea A. DC. 
Appendix 2. (cont.)

Key to symbols: - species sampled in quantitative study in size-class $>12 \mathrm{~cm} \mathrm{DBH}$; species sampled in quantitative study in size-class $6-12 \mathrm{~cm} \mathrm{DBH}$; [s] shrub $<3 \mathrm{~m}$ tall.

\section{Malpighiaceae}

Bunchosia gracilis Niedenzu

B. lanceolata Turcz.

B. matudae Lundell

Malpighia glabra L.

Malvaceae

Malvaviscus lanceolatus Rose

Robinsonella speciosa Fryxell

Melastomataceae

Miconia glaberrima (Schlecht.) Naud.

M. mexicana (Bonpl.) Naud.

Tibouchina longifolia (Vahl) Baillon ex Cogn.

Meliaceae

Guarea glabra Vahl

Trichilia havanensis Jacq.

Menispermaceae

Hyperbaena mexicana Miers vel aff.

Monimiaceae

Mollinedia pallida Lundell

Moraceae

Brosmium sp.

Coussapoa purpusii Standley

Ficus cookii Standley

Trophis chiapensis Brandegee •

T. mexicana (Liebm.) Bureau

\section{Myrsinaceae}

Ardisia siltepecana Lundell •

Ardisia sp.

Centardisia ovandensis (Lundell) Lundell (=Ardisia)

Myrsine juergensenii (Mez) Lundell

Parathesis sp.

\section{Myrtaceae}

Calyptranthes pallens var. mexicana (Lundell) McVaugh

Eugenia biflora (L.) DC.

E. capulioides Lundell

E. nigrita Lundell vel aff.

\section{Olacaceae}

Heisteria acuminata Benth. \& Hook. f. [s]

\section{Oleaceae}

Osmanthus americanus (L.) Benth. \& Hook.

\section{Onagraceae}

Fuchsia paniculata Lindley

Hauya elegans H.B.K. ssp. barcenae (Hemsley) Breedlove \& Raven 


\section{Piperaceae}

Piper auritum H.B.K.

P. glabrescens (Miq.) C. DC.

P. pseudo-lindenii C. DC. [s]

$P$. sancti-felicis Trel. [s]

Piper sp.

Pothomorphe umbellata (L.) Miq. [s]

Podocarpaceae

Podocarpus matudae Lundell

Polygonaceae

Coccoloba matudae Lundell

Coccoloba sp.

Proteaceae

Roupala montana Aublet

Rhamnaceae

Rhamnus mucronata Schlecht.

R. sharpii M.C. Johnston

Rosaceae

Prunus tetradenia Koehne

Rubiaceae

Balmea stormae Martínez

Bouvardia dictyoneura Standley [s]

Chiococca pachyphylla Wernham

Chione chiapensis Standley

Chomelia brachypoda J.D. Smith.

C. protracta (Bartling) Standley

Coffea arabica L.

Deppea inaequalis Standley \& Steyerm. [s]

Deppea sp. [s]

Genipa americana L.

Glossostipula concinna (Standley) D. Lorence

Gonzalagunia chiapensis (Standley) Standley \& Steyerm.

Hamelia barbata Standley [s]

Hintonia lumaeana (Baillon) Bullock

Hoffmannia angustifolia Standley

H. cryptoneura Standley [s]

Omiltemia filisepala (Standley) Morton [s]

Palicourea padifolia (Willd. ex R \& S.) Taylor \& Lorence

Plocaniophyllon flavum Brandegee [s]

Psychotria mexiae Standley [s]

$P$. pubescens Sw. vel aff.

$P$. quinqueradiata Polak. [s]

Psychotria sp. [s]

Randia grandifolia (J.D. Smith) Standley

Rondeletia albida Lundell [s]

$R$. intermedia Hemsley

$R$. ovandensis Lundell •

Rondeletia sp.

Sommera arborescens Schlecht.

Sabiaceae

Meliosma matudae Lundell 
Appendix 2. (cont.)

Key to symbols: species sampled in quantitative study in size-class $>12 \mathrm{~cm} \mathrm{DBH}$; species sampled in quantitative study in size-class 6-12 cm DBH; [s] shrub $<3 \mathrm{~m}$ tall.

\section{Sapindaceae}

Cupania macrophylla A. Rich. vel aff.

Exothea paniculata (Juss.) Radlk.

Sapotaceae

Dipholis minutiflora Pittier $\bullet \bullet$

Sideroxylum capiri Pittier

Scrophulariaceae

Russelia sarmentosa Jacq. [s]

Simaroubaceae

Picramnia antidesma var. fessoniana (DC.) Thomas

$P$. matudae Lundell [s]

Picrasma sp.

Solanaceae

Cestrum luteovirescens Francey [s]

Lycianthes arrazolensis (Coult. \& J.D. Smith) Bitter [s]

L. orogenes Standley \& Steyerm.

Lycianthes sp. [s]

Solanum chiapense Roe [s]

S. chrysotrichum Schlecht. [s]

S. diphyllum L. [s]

Witheringia solanacea L'Her. [s]

Styracaceae

Styrax glabrescens var. pilosus (Perkins) Standley •

Theaceae

Cleyera theaeoides (Sw.) Choisy [s]

Symplococarpon flavifolium Lundell

Ternstroemia oocarpa (Rose) Melchior

Thymelaeaceae

Daphnopsis flavida Lundell •

Tiliaceae

Triumfetta dumetorum Schlecht. [s]

T. speciosa Seem.

Ulmaceae

Celtis caudata Planchon vel. aff

Ulmus mexicana Liebm.

Urticaceae

Myriocarpa longipes Liebm.

Phenax hirtus (Sw.) Wedd. [s]

Urera alceifolia Gaud.

Verbenaceae

Aegiphila valerii Standley 


\section{References}

Alvarez, F. (1988) Peasant movements in Chiapas. Bull. Latin Amer. Res. 7: 277-298.

Alvarez del Toro, M. (1986) Así era Chiapas. Tuxtla Gutiérrez, Chiapas: Fundación Chiapeneco.

Binford, L. C. (1989) A distributional survey of the birds of the state of Oaxaca. Washington, D.C.: American Ornithologists' Union (Orn. Monogr. 43).

Breedlove, D. E. (1973) The phytogeography and vegetation of Chiapas (Mexico). Pp. 149-165 in A. Graham, ed. Vegetation and vegetational history of northern Latin America. Amsterdam: Elsevier Scientific Publishing.

Breedlove, D. E. (1981) Introduction to the flora of Chiapas. Part 1. San Francisco: California Academy of Sciences.

Breedlove, D. E. (1986) Listados florísticos de México. IV. Flora de Chiapas. Mexico D.F.: Instituto de Biología, Universidad Autónoma de México.

Brodkorb, P. (1939) Rediscovery of Heleodytes chiapensis and Tangara cabanisi. Auk 56: $447-450$.

Cabanis, J. (1866) Uber neue oder weniger bekannte exotische Vögel. J. Orn. 14: 159-165.

Campbell, D. G. (1990) Quantitative inventory of tropical forest. Pp. 523-533 in D. G. Campbell and H. D. Hammond, eds. Floristic inventory of tropical countries: the status of plant systematics, collections, and vegetation, plus recommendations for the future. Bronx, New York: New York Botanical Garden.

Campbell, D. G., Daly, D. C., Prance, G. T. and Maciel, U. N. (1986) Quantitative ecological inventory of terra firme and varzea tropical forest on the Rio Xingu, Brazilian Amazon. Brittonia 38: 369-393.

Crossin, R. S. and Ely, C. A. (1973) A new race of Sumichrast's Wren from Chiapas, Mexico. Condor 75: 137-139.

Curtis, J. T. (1955) A note on recent work dealing with the spatial distribution of plants. J. Ecol. 43: 309.

García, E. (1981) Modificaciones al sistema de clasificación climática de Koppen (para adaptarlo a las condiciones de la República Mexicana). Third Edition. México D.F.: Offset Larios.

Hellmayr, C. E. (1936) Catalogue of birds of the Americas: Part IX TersinidaeThraupidae. Field Mus. Nat. Hist. Ser. Zool. 13.

Hilty, S. L. and Simon, D. (1977) The Azure-rumped Tanager in Mexico with comparative remarks on the Gray-and-gold Tanager. Auk 94: 605-606.

Hubbell, S. P. and Foster, R. B. (1986) Commonness and rarity in a neotropical forest: implications for tropical tree conservation. Pp. 205-231 in M. E. Soulé, ed. Conservation biology, the science of scarcity and diversity. Sunderland, MA: Sinauer Associates, Inc.

Instituto de Historia Natural (1986) Taller sobre planificación de áreas silvestres protegidas. Plan operativo. Propuesta Reserva Ecológica El Triunfo. Mayo 1-17, 1986. Tuxtla Gutiérrez, Chiapas: Instituto de Historia Natural.

Instituto de Historia Natural (1988) Informe final de actividades plan operativo 1987-1988 Reserva Ecologica "El Triunfo". Tuxtla Gutiérrez, Chiapas: Instituto de Historia Natural.

INEGI (1986) Guía para los mapas cartográficos de INEGI. México, D.F.: Instituto Nacional de Estadística, Geografía y Informática.

Isler, M. L. and Isler, P. R.(1987) The tanagers: natural history, distribution and identification. Washington, D.C.: Smithsonian Institution Press.

Jost, L. (1989) A Chiapan mountain mystery: the Azure-rumped Tanager and its nesting grounds revealed. Birder's World 3: 26-28.

King, W. B. (1978-1979) Red data book, 2. Aves. Second edition, Morges, Switzerland: International Union for Conservation of Nature and Natural Resources. 
Land, H. C. (1970) Birds of Guatemala. Wynnewood, Pennsylvania: Livingston Publishing Company.

Long, A. J. and Heath, M. F. (in press) Flora of the El Triunfo Biosphere Reserve, Chiapas, Mexico: a preliminary floristic inventory and descriptions of the plant communities of Polygon 1. An. Inst. Biol. Univ. Nac. México, Ser. Bot.

Miranda, F. (1952) La vegetación de Chiapas, 1. Tuxtla Gutiérrez, Chiapas: Ediciones del Gobierno del Estado.

Miranda, F. (1957) Vegetación de la vertiente del Pacífico de la Sierra Madre de Chiapas (México) y sus relaciones florísticas. Proc. 8th Pac. Sci. Congr. 4: 438-453.

Miranda, F. and Hernández X., E. (1963) Los tipos de vegetación de México y su clasificación. Bol. Soc. Bot. México 28: 29-179.

Müller-Dombois, D. and Ellenberg, H. (1974) Aims and methods of vegetation ecology. New York: John Wiley and Sons.

Mülleried, F. K. G. (1957) La geologia de Chiapas. Tuxtla Gutiérrez: Gobierno Constitucional del Estado de Chiapas.

Rzedowski, J. (1978) Vegetación de México. México D.F.: Editorial Limusa.

Sclater, P. L. (1868) On a recently discovered Tanager of the genus Calliste. Ibis 4: 71.

Standley, P. C. and Steyermark, J. A. (1946) Flora of Guatemala: Part IV. Fieldiana Bot. 24: $10-58$.

University of East Anglia (1989) U.E.A. Mexican rainforest report, 1988. Unpublished.

University of East Anglia (1990) U.E.A. Mexican rainforest report, 1989. Unpublished.

MELANIE HEATH*

Instituto de Historia Natural, Apartado Postal \# 6, Tuxtla Gutiérrez, Chiapas, CP29000, México.

ADRIAN LONG*

Instituto de Historia Natural, Apartado Postal \# 6, Tuxtla Gutiérrez, Chiapas, CP29ooo, México.

*Present address: International Council for Bird Preservation, 32 Cambridge Road, Girton, Cambridge $\mathrm{CB}_{3}$ oPI, U.K. 